\title{
Small Animal Models of Respiratory Viral Infection Related to Asthma
}

\author{
Mingyuan Han ${ }^{1}$ (D), Charu Rajput ${ }^{1}$, Tomoko Ishikawa ${ }^{1}$, Caitlin R. Jarman ${ }^{1}$, Julie Lee ${ }^{1}$ and \\ Marc B. Hershenson 1,2,* \\ 1 Department of Pediatrics and Communicable Diseases, University of Michigan Medical School, \\ Ann Arbor, MI 48109, USA; hanming@umich.edu (M.H.); crajput@umich.edu (C.R.); \\ toishika@umich.edu (T.I.); cablake@umich.edu (C.R.J.); leejul@umich.edu (J.L.) \\ 2 Department of Molecular and Integrative Physiology, University of Michigan Medical School, \\ Ann Arbor, MI 48109, USA \\ * Correspondence: mhershen@umich.edu; Tel.: +734-936-4200; Fax: +734-764-3200
}

Received: 31 October 2018; Accepted: 29 November 2018; Published: 1 December 2018

\begin{abstract}
Respiratory viral infections are strongly associated with asthma exacerbations. Rhinovirus is most frequently-detected pathogen; followed by respiratory syncytial virus; metapneumovirus; parainfluenza virus; enterovirus and coronavirus. In addition; viral infection; in combination with genetics; allergen exposure; microbiome and other pathogens; may play a role in asthma development. In particular; asthma development has been linked to wheezing-associated respiratory viral infections in early life. To understand underlying mechanisms of viral-induced airways disease; investigators have studied respiratory viral infections in small animals. This report reviews animal models of human respiratory viral infection employing mice; rats; guinea pigs; hamsters and ferrets. Investigators have modeled asthma exacerbations by infecting mice with allergic airways disease. Asthma development has been modeled by administration of virus to immature animals. Small animal models of respiratory viral infection will identify cell and molecular targets for the treatment of asthma.
\end{abstract}

Keywords: animal model; asthma; respiratory disease; rhinovirus; viral infection

\section{Introduction}

Asthma is a chronic inflammatory disorder of the conducting airways with reversible airflow obstruction and associated with mucus overproduction and airway remodeling. Though asthma is defined by typical symptoms such as cough, wheeze, chest tightness and/or shortness of breath, it has become increasingly recognized that asthma represents a heterogeneous disease with multiple phenotypes. Most children and roughly $50 \%$ of adult asthma patients have allergic asthma [1]. Allergic asthmatic patients have airway eosinophilic inflammation in parallel with increased type $2 \mathrm{~T}$ helper (Th2) cells and excessive production of type 2 cytokines such as IL-4, IL-5 and IL-13, as well as increased levels of $\operatorname{IgE}[2,3]$.

Respiratory viral infections are strongly associated with asthma exacerbations. Human rhinovirus (HRV) is most frequently-detected pathogen, followed by human respiratory syncytial virus (RSV), human metapneumovirus (hMPV), human parainfluenza virus (hPIV), human enterovirus (EV), human bocavirus (HBoV) and human coronavirus (HCoV) (Table 1) 
Table 1. Asthma-associated respiratory viruses and infection susceptibility in small animals.

\begin{tabular}{|c|c|c|c|c|c|c|c|c|}
\hline \multicolumn{4}{|c|}{ Taxonomy } & \multicolumn{5}{|c|}{ Species } \\
\hline Order & Family & $\begin{array}{l}\text { Subfamily and } \\
\text { Genus }\end{array}$ & Species & Mice & Rats & Guinea Pigs & Hamsters & Ferrets \\
\hline \multirow[b]{2}{*}{ Picornavirales } & \multirow[b]{2}{*}{ Picornaviridae } & \multirow[b]{2}{*}{ Enterovirus } & Rhinovirus $A-C$ & $\begin{array}{c}\text { HRVA-1B [4,5] } \\
\text { HRV-A16 [4] }\end{array}$ & $\begin{array}{l}\text { HRVA-16 [6] } \\
\text { HRVB-14 [7] }\end{array}$ & & & \\
\hline & & & Enterovirus D & $\begin{array}{l}\text { EV-D68 [8-10] } \\
\text { Fermon and } \\
\text { epidemic strains }\end{array}$ & $\begin{array}{l}\text { EV-D68 [11] } \\
\text { Fermon and } \\
\text { epidemic strains }\end{array}$ & & & $\begin{array}{l}\text { EV-D68 [12] } \\
\text { Fermon strain }\end{array}$ \\
\hline \multirow{6}{*}{ Mononegavirales } & \multirow{3}{*}{ Pneumoviridae } & \multirow{2}{*}{ Orthopneumovirus } & $\begin{array}{c}\text { Human } \\
\text { orthopneumovirus }\end{array}$ & human RSV-A [13] & human RSV-A [14] & human RSV-A [15] & human RSV-A [16] & human RSV-A [17] \\
\hline & & & $\begin{array}{c}\text { Murine } \\
\text { orthopneumovirus }\end{array}$ & PVM [18] & & & & \\
\hline & & Metapneumovirus & & hMPV [19] & hMPV [20] & hMPV [21] & hMPV $[21,22]$ & hMPV [23] \\
\hline & \multirow{3}{*}{ Paramyxoviridae } & Respirovirus & $\begin{array}{c}\text { Human } \\
\text { Respirovirus } 1,3\end{array}$ & & hPIV3 [24] & hPIV3 [25] & hPIV3 [26] & hPIV3 [27] \\
\hline & & & $\begin{array}{c}\text { Murine } \\
\text { Respirovirus }\end{array}$ & $\mathrm{SeV}[28]$ & $\mathrm{SeV}$ [29] & $\mathrm{SeV}$ [30] & $\mathrm{SeV}[31]$ & \\
\hline & & Rubulavirus & $\begin{array}{c}\text { Human } \\
\text { Respirovirus 2,4 }\end{array}$ & & & & & \\
\hline
\end{tabular}


Asthma development is most probably caused by an interaction of multiple factors, including, genetics, allergen exposure, microbiome and invading pathogens [32-34]. In particular, asthma development has been linked to wheezing-associated respiratory viral infections in early life [35-37]. It is unclear whether wheezing-associated respiratory viral infections cause asthma or are simply a marker of asthma susceptibility.

Multiple infection models have been applied to explore the basic mechanisms of viral-induced asthma development and exacerbation. Primary epithelial cells, monocytes/macrophages and other cell types from either healthy control or asthmatic patients are usually collected and cultured for subsequent viral infection and measurement of cytokine/chemokine expression [38-43]. However, use of cultured cells limits the scope of research to cell-specific responses and prevents the study to cell-to-cell interactions or coordinated immune responses. Experimental infection of human subjects is available [44,45] but such studies may not always be feasible due to the safety concerns and difficulties in volunteer recruitment. Consequently, small animal models have been developed to better understand the mechanisms by which respiratory infection induce asthma and asthma exacerbation.

Asthma exacerbations are modeled in small animal models by sensitization and challenge with allergens such as ovalbumin (OVA) [4,46,47], dust house mite (HDM) [48-50] or cockroach allergen [51,52], thereby generating a mouse with allergic airways disease, followed by viral infection (Figure 1). Asthma development is modeled in small animals by administration of virus in immature mice [53-55].
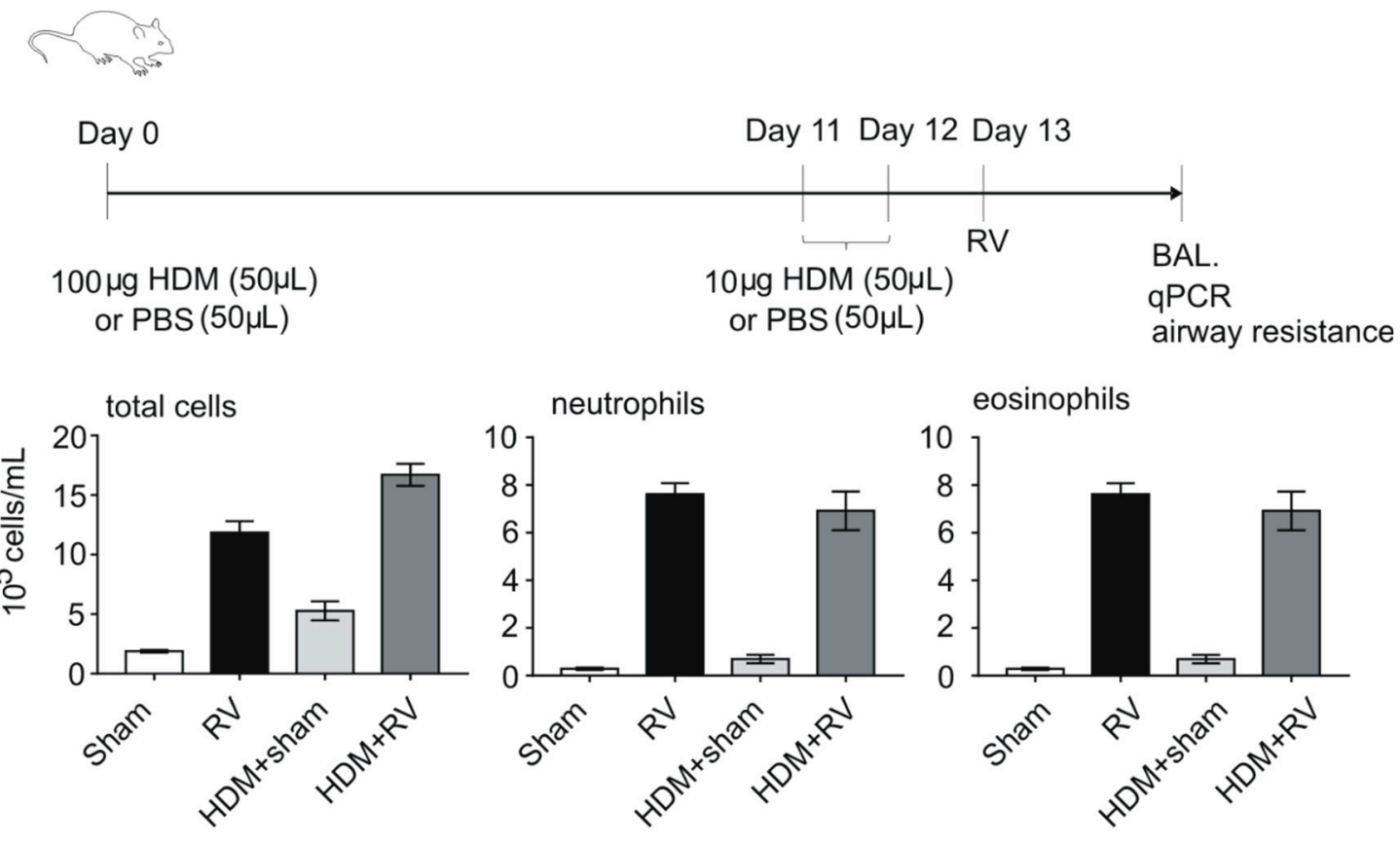

Figure 1. Example of an allergen sensitization and challenge model of allergic airways disease. Following the last challenge, mice are infected with human rhinovirus (HRV) to simulate an asthma exacerbation. The combination of house dust mite (HDM) exposure and viral infection induces an additive increase in airway eosinophils. 
To date, mice, rats, ferrets, hamsters and guinea pigs (Tables 1-3) have been extensively used for modeling human respiratory virus infections. The availability of immunological reagents and the convenience of genetic manipulation (transgenic and gene knockout mice) makes the mouse model the most commonly employed. Although most human respiratory viruses are not natural mouse pathogens and therefore require high-dose inoculums, mouse models have provided insights into mechanisms of pathology, immunology and vaccine biology. In this review, we summarize the small animal models of human respiratory viral infection relevant to asthma exacerbation and development, including HRV, RSV, EV-D68, hMPV and hPIV, as well as their contribution to the understanding of virus-induced asthma development and exacerbation. We also mention to mouse respiratory viruses which have been used to model viral-induced asthma, Sendai virus and pneumonia virus of mouse (PVM).

Of note, we include only a limited discussion of $\mathrm{HCoVs}$ because most animal models have been established for the study of severe acute respiratory syndrome (SARS)-CoV and Middle East respiratory syndrome (MERS)-CoV which are less relevant to asthma. Finally, for the same reason, we do not include a description of animal models of influenza infection. 
Table 2. Mouse models for respiratory viral infection.

\begin{tabular}{|c|c|c|c|c|c|c|c|c|c|c|}
\hline Viruses & Species $^{\text {a }}$ & Age & Gender $^{b}$ & Route $^{c}$ & $\begin{array}{c}\text { Virus } \\
\text { Strains/Isolates }\end{array}$ & Inoculum ${ }^{d}$ & Dura-Tion ${ }^{e}$ & $\begin{array}{l}\text { Detection } \\
\text { Method }\end{array}$ & $\begin{array}{l}\text { Applications and Major } \\
\text { Observations }\end{array}$ & Reference \\
\hline \multirow{4}{*}{ HRV } & $\begin{array}{l}\mathrm{BALB} / \mathrm{c} \\
\text { mice }\end{array}$ & 6 weeks & $\mathrm{F}$ & i.n. & HRVA-1B & $\begin{array}{l}5 \times 10^{6} \\
\mathrm{TCID}_{50}\end{array}$ & $72-96 \mathrm{~h}$ & $\begin{array}{c}\text { Viral titer/ } \\
\text { Viral RNA/ } \\
\text { v(-) RNA }\end{array}$ & $\begin{array}{c}\text { HRV induced airway inflammation } \\
\text { with inflammatory infiltrates and } \\
\text { increased expression of cytokines, } \\
\text { chemokines and IFNs as well as } \\
\text { mucus-related proteins }\end{array}$ & [4] \\
\hline & $\begin{array}{c}\text { huICAM } \\
\text { BALB /c } \\
\text { mice }\end{array}$ & N/A & $\mathrm{N} / \mathrm{A}$ & i.n. & HRVA-16 & $\begin{array}{l}5 \times 10^{6} \\
\mathrm{TCID}_{50}\end{array}$ & $\mathrm{~N} / \mathrm{A}$ & Viral RNA/ & & \\
\hline & $\begin{array}{l}\text { C57BL } / 6 \\
\text { mice }\end{array}$ & 6-8 weeks & $\mathrm{F}$ & i.n. & HRVA-1B & $\begin{array}{l}5 \times 10^{6} \\
\mathrm{TCID}_{50}\end{array}$ & $96 \mathrm{~h}$ & $\begin{array}{l}\text { Viral RNA/ } \\
\text { v(-) RNA }\end{array}$ & $\begin{array}{c}\text { HRV induced phosphatidylinositol } \\
\text { 3-kinase dependent airway } \\
\text { inflammation and airway } \\
\text { responsiveness }\end{array}$ & [5] \\
\hline & $\begin{array}{l}\mathrm{BALB} / \mathrm{c} \\
\text { mice }\end{array}$ & 6 days & $\mathrm{N} / \mathrm{A}$ & i.n. & HRVA-1B & $\begin{array}{l}2 \times 10^{6} \\
\mathrm{TCID}_{50}\end{array}$ & $7 \mathrm{~d}^{*}$ & Viral RNA/ & $\begin{array}{l}\text { Neonatal model of HRV infection. } \\
\text { Early-life HRV infection induced the } \\
\text { development of asthma like } \\
\text { phenotype which is IL-13 dependent } \\
\text { and ILC2 expansion }\end{array}$ & {$[53,56]$} \\
\hline EV-D68 & $\begin{array}{l}\mathrm{BALB} / \mathrm{c} \\
\text { mice }\end{array}$ & $8-12$ weeks & $\mathrm{F}$ & i.n. & US/MO/14-18947 & $5 \times 10^{6} \mathrm{epfu}$ & $96 \mathrm{~h}$ & Viral RNA & $\begin{array}{l}\text { EV-D68 infection induces } \\
\text { IL-17-dependent airway inflammation } \\
\text { and hyperresponsiveness which is } \\
\text { greater than HRV in naïve mice }\end{array}$ & [9] \\
\hline \multirow{3}{*}{$\begin{array}{l}\text { Human } \\
\text { RSV }\end{array}$} & 20 strains & 3 days & N/A & i.n. & Long strain & $10^{3.3}-10^{3.7} \mathrm{pfu}$ & N/A & Viral titer & $\begin{array}{l}\text { The susceptibility of HRSV infection is } \\
\text { different among } 20 \text { strains of inbred } \\
\text { 3-day old mice. DBA/ } 2 \mathrm{~N} \text { is the most } \\
\text { permissive strain. }\end{array}$ & [13] \\
\hline & 8 strains & $8-10$ weeks & $\mathrm{F}$ & i.t. & A2 strain & $4 \times 10^{7} \mathrm{pfu}$ & $\mathrm{N} / \mathrm{A}$ & Viral titer & $\begin{array}{c}\text { AKR/J is the most permissive among } \\
\text { eight strains of adult mice for human } \\
\text { RSV infection, C57BL/ } 6 \text { is the most } \\
\text { resistant }\end{array}$ & [57] \\
\hline & $\begin{array}{l}\mathrm{BALB} / \mathrm{c} \\
\text { mice }\end{array}$ & 1 day-32 weeks & N/A & i.n. & $\begin{array}{l}\text { A2 strain } \\
\text { Long strain }\end{array}$ & $10^{4}-10^{7} \mathrm{pfu}$ & $8-12 d *$ & Viral titer & $\begin{array}{l}\text { Human RSV causes weight loss, } \\
\text { bronchiolitis, pneumonia and } \\
\text { increased CD8+ T cell and NK cell } \\
\text { responses. RSV reinfection after early } \\
\text { primary infection causes more severe } \\
\text { disease. RSV persists in the lung. }\end{array}$ & [58-64] \\
\hline
\end{tabular}


Table 2. Cont

\begin{tabular}{|c|c|c|c|c|c|c|c|c|c|c|}
\hline Viruses & Species $^{a}$ & Age & Gender ${ }^{b}$ & Route $^{c}$ & $\begin{array}{c}\text { Virus } \\
\text { Strains/Isolates }\end{array}$ & Inoculum ${ }^{d}$ & Dura-Tion $^{e}$ & $\begin{array}{l}\text { Detection } \\
\text { Method }\end{array}$ & Applications and Major Observations & Reference \\
\hline \multirow{3}{*}{$\begin{array}{l}\text { Human } \\
\text { RSV }\end{array}$} & $\begin{array}{l}\mathrm{BALB} / \mathrm{c} \\
\text { mice }\end{array}$ & $6-8$ weeks & $\mathrm{N} / \mathrm{A}$ & i.n. & 6 clinical isolates & $10^{5} \mathrm{pfu}$ & $\mathrm{N} / \mathrm{A}$ & $\mathrm{N} / \mathrm{A}$ & $\begin{array}{l}\text { The clinical RSV isolate A2001/2-20 caused } \\
\text { more severe lung dysfunction, airway } \\
\text { responsiveness, IL-13 and mucus expression }\end{array}$ & [65] \\
\hline & $\begin{array}{l}\mathrm{BALB} / \mathrm{c} \\
\text { mice }\end{array}$ & 8 weeks & $\mathrm{N} / \mathrm{A}$ & i.n. & A2001/2-20 strain & $3 \times 10^{6} \mathrm{pfu}$ & $\mathrm{N} / \mathrm{A}$ & $\mathrm{N} / \mathrm{A}$ & $\begin{array}{l}\text { In adult mice, RSV A2001/2-20 strain triggers } \\
\text { expansion of IL-13 expressing ILC2s which is } \\
\text { TSLP dependent. }\end{array}$ & [66] \\
\hline & $\begin{array}{l}\mathrm{BALB} / \mathrm{c} \\
\text { mice }\end{array}$ & 5 days & $\mathrm{N} / \mathrm{A}$ & i.n. & $\begin{array}{l}\text { A2 strain } \\
\text { rA2-19F strain }\end{array}$ & $10^{4.68} \mathrm{TCID}_{50} / \mathrm{g}$ & $6 d^{*}$ & $\begin{array}{l}\text { Viral RNA } \\
\text { Viral titer }\end{array}$ & $\begin{array}{l}\text { Neonatal infection with recombinant human } \\
\text { RSV rA2-19F causes increased Th2 responses } \\
\text { at primary infection and augmented airway } \\
\text { hyperreactivity, mucus hyperproduction and } \\
\text { eosinophilia during reinfection compared to } \\
\text { the A2 strain. }\end{array}$ & [54] \\
\hline \multirow[t]{2}{*}{ HMPV } & $\begin{array}{l}\mathrm{BALB} / \mathrm{c} \\
\text { mice }\end{array}$ & $4-8$ weeks & $\mathrm{N} / \mathrm{A}$ & i.n. & $\begin{array}{l}\text { NL/100 strain } \\
\text { C-85473 strain } \\
\text { CAN98-75 strain } \\
\text { CAN98-83 strain }\end{array}$ & $5 \times 10^{5}-10^{8} \mathrm{pfu}$ & $21-60 \mathrm{~d}$ & Virus titer & $\begin{array}{l}\text { hMPV replicates with a biphasic growth } \\
\text { kinetic and persists in the lung. hMPV } \\
\text { induces both Th1 and Th2 responses. hMPV } \\
\text { infection causes clinical symptoms (dyspnea } \\
\text { and weight loss) as well as mucus production, } \\
\text { airway hyperresponsiveness and obstruction. }\end{array}$ & $\begin{array}{l}{[19,22,67-} \\
69]\end{array}$ \\
\hline & 9 strains & $5-6$ weeks & $\mathrm{N} / \mathrm{A}$ & i.n. & TN/96-12 strain & $10^{5} \mathrm{pfu}$ & $\mathrm{N} / \mathrm{A}$ & Virus titer & $\begin{array}{l}\text { DBA/2 mice is the most permissive strain for } \\
\text { hMPV. }\end{array}$ & [21] \\
\hline \multirow{2}{*}{$\begin{array}{l}\mathrm{HPIV} / \\
\mathrm{SeV}\end{array}$} & $\begin{array}{l}\text { C57BL/6 } \\
\text { mice }\end{array}$ & 6-12 weeks & $\mathrm{N} / \mathrm{A}$ & i.n. & Fushimi strain & $\begin{array}{l}2 \times 10^{5} \mathrm{pfu} / \\
5000 \mathrm{EID}_{50}\end{array}$ & $\mathrm{~N} / \mathrm{A}$ & $\mathrm{N} / \mathrm{A}$ & \multirow{2}{*}{$\begin{array}{l}\text { Acute } \mathrm{SeV} \text { infection leads to chronic airway } \\
\text { hyperresponsiveness and mucus metaplasia, } \\
\text { along with increased and maintained IL-13 } \\
\text { expression by CD4+ T cells and macrophages. }\end{array}$} & {$[28,70,71]$} \\
\hline & $\begin{array}{l}\mathrm{BALB} / \mathrm{c} \\
\text { mice }\end{array}$ & $6-8$ weeks & F & i.n. & $\mathrm{N} / \mathrm{A}$ & $500 \mathrm{EIU}$ & $\mathrm{N} / \mathrm{A}$ & $\mathrm{N} / \mathrm{A}$ & & [72] \\
\hline
\end{tabular}

${ }^{a}$ Different inbred mice strains have been used to compare their susceptibility for the infection of a certain respiratory virus strain. ${ }^{\mathrm{b}}$ For gender, $\mathrm{F}=$ female, $\mathrm{M}=$ male, $\mathrm{N} / \mathrm{A}=$ not applicable.

${ }^{c}$ Animals were inoculated by the intranasal (i.n.), intratracheal (i.t.) routes. ${ }^{d}$ Viral titers were quantified by different units: plaque forming units (pfu), $50 \%$ tissue culture infectious

dose $\left(\mathrm{TCID}_{50}\right), 50 \%$ egg infectious dose (EID 50$)$, egg infectious unit (EIU). ${ }^{\text {e }}$ The symbol “*” indicates the duration of the infection ended due to the termination of time course study.

$\mathrm{N} / \mathrm{A}=$ not applicable. 
Table 3. Other small animal models of respiratory viral infection.

\begin{tabular}{|c|c|c|c|c|c|c|c|c|c|}
\hline Viruses & Species & Age & Gender & Routes & $\begin{array}{c}\text { Virus } \\
\text { Strain/isolates } \\
\end{array}$ & Inoculum & Duration & Detection Method & Reference \\
\hline \multirow{2}{*}{ HRV } & $\begin{array}{c}\text { Cotton rat } \\
\text { (Sigmodon hispidus) }\end{array}$ & 8 weeks & $\mathrm{F} / \mathrm{M}$ & i.n. & HRVA-16 & $10^{7} \mathrm{pfu}$ & $48 \mathrm{~h}$ & Viral titer/v(-) RNA & [6] \\
\hline & $\begin{array}{c}\text { Cotton rat } \\
\text { (Sigmodon hispidus) }\end{array}$ & $4-6$ weeks & $\mathrm{N} / \mathrm{A}$ & i.n. & HRVB-14 & $3.97 \times 10^{6} \mathrm{pfu}$ & $48 \mathrm{~h}$ & Viral titer/v(-) RNA & [7] \\
\hline \multirow[t]{2}{*}{ EV-D68 } & $\begin{array}{c}\text { Cotton Rat } \\
\text { (Sigmodon hispidus) }\end{array}$ & $6-8$ weeks & $\mathrm{F}$ & i.n. & $\begin{array}{c}\text { Fermon } \\
\text { VANBT/1 } \\
\text { US/MO/14/18949 }\end{array}$ & $\begin{array}{l}10^{6} \mathrm{pfu} \\
10^{6} \mathrm{pfu} \\
10^{6} \mathrm{pfu}\end{array}$ & $\begin{array}{l}\text { N/A } \\
24 \mathrm{~h} \\
\mathrm{~N} / \mathrm{A}\end{array}$ & $\begin{array}{c}\text { Viral titer } \\
\text { Viral titer/v(-) RNA } \\
\text { Viral titer }\end{array}$ & [11] \\
\hline & $\begin{array}{c}\text { Ferret } \\
\text { (Mustela putorius furo) } \\
\end{array}$ & $\mathrm{N} / \mathrm{A}$ & M & aerosol spray & Fermon & $10^{4.5}$ CCID50 & $15 d^{*}$ & Viral RNA & [12] \\
\hline \multirow{3}{*}{ Human RSV } & $\begin{array}{c}\text { Cotton rat } \\
\text { (Sigmodon hispidus) }\end{array}$ & $1-28$ days & N/A & i.n. & Long & $10^{4} \mathrm{pfu}$ & $7 \mathrm{~d}$ & Virus titer & [14] \\
\hline & $\begin{array}{c}\text { Ferret } \\
\text { (Mustela putorius furo) }\end{array}$ & $1-28$ days & $\mathrm{N} / \mathrm{A}$ & i.n. & Long & $3.6 \times 10^{3} \mathrm{pfu}$ & $9 d$ & Virus titer & [17] \\
\hline & $\begin{array}{c}\text { guinea pigs } \\
\text { (Cam Hartley) }\end{array}$ & N/A & Female & i.n. & Long & $3.9 \times 10^{3} \mathrm{pfu}$ & $14 d^{*}$ & Viral titer & {$[15,73]$} \\
\hline \multirow{5}{*}{ hMPV } & Cotton rat & $\begin{array}{c}5 \text { weeks } \\
5-6 \text { weeks }\end{array}$ & $\begin{array}{l}\text { N/A } \\
\text { N/A }\end{array}$ & $\begin{array}{l}\text { i.n. } \\
\text { i.n. }\end{array}$ & $\begin{array}{l}\text { NL/100 } \\
\text { TN/96-12 }\end{array}$ & $\begin{array}{l}10^{6} \mathrm{pfu} \\
10^{5} \mathrm{pfu}\end{array}$ & $\begin{array}{l}\text { N/A } \\
8 \mathrm{~d}\end{array}$ & $\begin{array}{c}\mathrm{N} / \mathrm{A} \\
\text { Virus titer }\end{array}$ & $\begin{array}{l}{[22]} \\
{[21]}\end{array}$ \\
\hline & (Sigmodon hispidus) & $\mathrm{N} / \mathrm{A}$ & $\mathrm{N} / \mathrm{A}$ & i.n. & $\begin{array}{l}\text { 26583(subtype A) } \\
\text { 26575(subtype B) }\end{array}$ & $9 \times 10^{5} \mathrm{TCID}_{50}$ & $14 \mathrm{~d}$ & $\mathrm{~N} / \mathrm{A}$ & [20] \\
\hline & $\begin{array}{c}\text { Ferrets } \\
\text { (Mustela putorius) }\end{array}$ & 5 weeks & $\mathrm{N} / \mathrm{A}$ & i.n. & NL/100 & $10^{6} \mathrm{pfu}$ & N/A & $\mathrm{N} / \mathrm{A}$ & [22] \\
\hline & $\begin{array}{c}\text { Hamster } \\
\text { (Mesocricetus auratus) }\end{array}$ & $\begin{array}{l}5 \text { weeks } \\
5-6 \text { weeks }\end{array}$ & $\begin{array}{l}\mathrm{N} / \mathrm{A} \\
\mathrm{N} / \mathrm{A}\end{array}$ & $\begin{array}{l}\text { i.n. } \\
\text { i.n. }\end{array}$ & $\begin{array}{c}\text { NL/100 } \\
\text { TN/96-12 }\end{array}$ & $\begin{array}{l}10^{6} \mathrm{pfu} \\
10^{5} \mathrm{pfu}\end{array}$ & $\begin{array}{l}\mathrm{N} / \mathrm{A} \\
\mathrm{N} / \mathrm{A}\end{array}$ & $\begin{array}{c}\mathrm{N} / \mathrm{A} \\
\text { Virus titer }\end{array}$ & $\begin{array}{l}{[22]} \\
{[21]}\end{array}$ \\
\hline & $\begin{array}{c}\text { guinea pigs } \\
\text { (Cavia porcellus) }\end{array}$ & 5-6 weeks & $\mathrm{N} / \mathrm{A}$ & i.n. & $\mathrm{TN} / 96-12$ & $10^{5} \mathrm{pfu}$ & $\mathrm{N} / \mathrm{A}$ & Virus titer & [21] \\
\hline \multirow{4}{*}{ hPIV } & $\begin{array}{c}\text { Cotton rat } \\
\text { (Sigmodon hispidus) }\end{array}$ & $\mathrm{N} / \mathrm{A}$ & $\mathrm{N} / \mathrm{A}$ & i.n. & hPIV3/F518 & $10^{5.8} \mathrm{pfu}$ & $8 \mathrm{~d}$ & Virus titer & [24] \\
\hline & $\begin{array}{c}\text { Cotton rat } \\
\text { (Sigmodon fulviventer) }\end{array}$ & $\mathrm{N} / \mathrm{A}$ & $\mathrm{N} / \mathrm{A}$ & i.n. & hPIV3/F518 & $10^{5.8} \mathrm{pfu}$ & $8 \mathrm{~d}$ & Virus titer & [24] \\
\hline & Ferret & 1 day & $\mathrm{N} / \mathrm{A}$ & Aerosolization & $\begin{array}{l}\text { HPIV3/224466 } \\
\text { HPIV3/C243 }\end{array}$ & $\mathrm{N} / \mathrm{A}$ & N/A & $\mathrm{N} / \mathrm{A}$ & [27] \\
\hline & $\begin{array}{c}\text { Hamster } \\
\text { (Mesocricetus auratus) }\end{array}$ & $\mathrm{N} / \mathrm{A}$ & N/A & i.n. & hPIV3 strain C243 & $100-6000 \mathrm{pfu}$ & $7-8 \mathrm{~d}$ & Virus titer & [26] \\
\hline \multirow{7}{*}{$\mathrm{SeV}$} & $\mathrm{Crl}: \mathrm{CD}(\mathrm{SD})$ rat & $5-25$ days & N/A & i.n. & N/A & $10^{2.4} \mathrm{TCID}_{50}$ & $7-10 \mathrm{~d}$ & Virus titer & [74] \\
\hline & Crl:CD(SD) rat & 5-25 days & N/A & Aerosol exposure & N/A & $1.34 \mathrm{pfu} / \mathrm{mL}$ gas & N/A & N/A & [75] \\
\hline & Crl:CD(SD) rat & 10 weeks & Male & Aerosol exposure & SeV P3193 & 1-3 pfu/mL gas & N/A & $\mathrm{N} / \mathrm{A}$ & [76] \\
\hline & Crl:CD(SD) rat & 5 days & N/A & Aerosol exposure & SeV P3193 & $1-2 \mathrm{pfu} / \mathrm{mL}$ gas & N/A & N/A & [77] \\
\hline & Brown Norway rat & 5-25 days & $\mathrm{N} / \mathrm{A}$ & aerosol exposure & SeV P3193 & 1-3 pfu/mL gas & N/A & $\mathrm{N} / \mathrm{A}$ & \\
\hline & Fischer 334 rat & 5-25 days & $\mathrm{N} / \mathrm{A}$ & aerosol exposure & SeV P3193 & 1-3 pfu/mL gas & $\mathrm{N} / \mathrm{A}$ & $\mathrm{N} / \mathrm{A}$ & [29] \\
\hline & Guinea pigs & N/A & Male & i.n. & SeV52 & $5 \times 10^{5} \mathrm{TCID}_{50}$ & $\mathrm{~N} / \mathrm{A}$ & $\mathrm{N} / \mathrm{A}$ & [30] \\
\hline
\end{tabular}

The symbol "** indicates the duration of the infection ended due to the termination of time course study. N/A = not applicable. 


\section{Human Rhinovirus (HRV)}

\subsection{Virology and HRV-Induced Airways Disease}

HRV is a small picornavirus grouped into the genus Enterovirus. HRV has an icosahedral, non-enveloped viral capsid carrying a positive sense, single-stranded RNA genome of approximately $7200 \mathrm{bp}[78,79]$. There are now 167 serotypes of HRV in three phylogenetic species, HRV-A, HRV-B and HRV-C [80]. HRV-A and HRV-B serotypes are also classified into two groups, major and minor, on the basis of receptor specificity, either intercellular adhesion molecule-1 (ICAM-1) [81-83] or low-density lipoprotein receptor (LDLR) [84], respectively. Cadherin-related family member 3 (CDHR3) serves as a receptor for the recently discovered HRV-C $[85,86]$.

HRV, first identified in 1950s, is the most common cause of upper respiratory tract infection [87,88]. Accumulating evidence has determined the presence of HRV in the lower airway tract [89-96]. HRV is now recognized to be a common cause of asthma and COPD exacerbations. PCR-based studies examining the presence of viruses among patients when sick and healthy show a higher prevalence of viral infection during exacerbations. Outpatient children with asthma attacks show 62-81\% positivity for viral infection versus only well children with $12-41 \%$ positivity [35,97]. Picornaviruses (primarily HRV) were detected in $65 \%$ of cases, coronaviruses in $17 \%$, influenza and parainfluenza viruses in 9\% and RSV in 5\% [35]. Similar studies have been done in hospitalized children and adults [37,98-104]. Adults show a slightly lower number of viral infections during exacerbations. Finally, 22 to $64 \%$ of patients with COPD exacerbations are positive for virus versus 12 to $19 \%$ of non-exacerbating subjects [105-109]. In these studies, HRV is responsible for about half of the viral infections. The prevalence of rhinovirus may be even higher depending on the time of year. A recent study detected on HRV in $82 \%$ of all children admitted to an emergency room for acute asthma between January and July $[97,110]$. It should be noted that people with atopic asthma are not at greater risk of HRV infection than healthy individuals but suffer from more frequent, severe and longer-lasting lower respiratory tract symptoms [111].

In addition to its role in exacerbation of chronic airways diseases, accumulating evidence suggests a link between early-life wheezing-associated HRV infection and later asthma development. In a cohort study in Finland, HRV was detected in one third of infants hospitalized for wheezing and $60 \%$ of HRV-positive cases were diagnosed with asthma 6 years later [112]. According to the COAST (Childhood Origins of Asthma) birth cohort study, HRV wheezing illness during the first year of life were more associated with persistent wheezing at age 3 than HRSV and allergen sensitization [113]. Furthermore, in the same study, the following investigations showed nearly $90 \%$ of these patients with HRV-associated wheezing at age 3 had asthma developed at 6 years of age [114]. Finally, HRV was a significant risk factor for wheezing at age 13 whereas RSV was not [115].

\subsection{Animal Models of HRV Infection}

The development of a small animal model is useful to understand the pathogenesis of HRV infection. A major obstacle in developing a small animal model is that there are no known murine rhinoviruses. Due to poor sequence homology between human and mouse ICAM-1, major group serotypes like HRV-16 fail to infect mouse cell lines without artificial expression of human ICAM-1 or chimeric ICAM-1 with human domains [116,117]. On the contrary, the minor receptors, members of the LDLR superfamily, are evolutionarily highly conserved throughout species and a minor group serotype HRV-A1A infects mouse fibroblast cells without adaptation [118]. In addition, another minor group serotype HRV-A1B infects mouse cell lines and replicates more efficiently in mouse lower respiratory epithelial cell lines LA-4 and Mad-C3 than in the mouse fibroblast cell line (L) [117]. To improve replication of minor group HRVs in mouse cells, serial passages have been performed in mouse cell lines, alternately between mouse and human cell lines, or in vivo [119,120]. In addition, mouse L cells stably expressing human ICAM-1 (ICAM-L cells) have been used for HRV-A16 adaption [116]. The resulted mutations in the sequence encoding for $2 \mathrm{C}$ and $3 \mathrm{~A}$ viral protein account for the adapted 
phenotype for HRV-A16 [116] and HRV-A1A [119], respectively. However, these adapted viruses did not show improved replication in vivo.

Based on the in vitro findings, experimental animal models using either minor-group HRV strains in wild-type mice or major-group HRVs in transgenic mice expressing human ICAM-1 have been developed [4]. High doses $\left(5 \times 10^{6}\right.$ TCID50, tissue-culture infective dose) of HRV-A1B or HRV-A16 are needed to induce extensive peribronchial and perivascular inflammatory infiltrates, chemokines, pro-inflammatory cytokines and interferons (IFNs) [4,5]. The requirement for high titer HRV-A16 in transgenic mice expressing human ICAM-1 suggests there are other factors which limit replication in mice besides the viral receptor. HRV-A1B infection also increases the airway hyperresponsiveness to methacholine [5]. Although negative-stranded genomic RNA is detectable, indicative of virus replication, the mouse is only "semi-permissive" to HRV infection, based on the limited viral replication and rapid decline in viral RNA and titer within 24-48 h after infection [4,5,119]. The respiratory tract mucosal barrier may account for the declined viral titers, which may prevent the initial receptor binding of HRV or the later release of progeny from infected epithelial cells. Mice pretreated with hypochalorous acid maintain viral titers of a mouse-adapted HRV strain for $24 \mathrm{~h}$ and show a 1-log decrease after $48 \mathrm{~h}$ post infection in comparison with a 3-log decrease in non-pretreated mice [119]. Use of HRV animal models has elucidated important signaling pathways, proteins and receptors involved in HRV-mediated airway inflammation and airway hyperresponsiveness in naïve mice, including phosphatidylinositol 3-kinase [5], E3 ubiquitin ligase midline 1 (MID1) [49], tumor necrosis factor-related apoptosis-inducing ligand (TRAIL) [50], C-X-C motif chemokine receptor (CXCR) 2, tumor necrosis factor receptor (TNFR) 1 [121], melanoma differentiation-associated gene (MDA)-5, the adaptor protein for Toll-like receptor (TLR)-3 [122], chemokine (C-C motif) ligand (CCL)-7 [123], IFN regulatory factor (IRF)-7 [123] and TLR2 [124]. HRV-A1B infection of mice deficient in Tbet, a transcription factor required for Th1 differentiation, exhibits T helper cell-dependent airway eosinophilia and mucus production, suggesting that Th2 responses play an important role in driving features of allergic airway diseases during asthma exacerbations [125].

The cotton rat has recently been used to model HRV infection. In the cotton rats, major group strains HRV-A16 and HRV-B14 infect and replicate better than minor group HRV-A1B [6,7]. The receptor employed by these major group HRVs has not yet determined. Of note, currently, there is no available animal model for HRV C strains.

\subsection{Models of HRV-Induced Asthma Exacerbation}

A major focus of animal models has been to elucidate the immune responses to HRV in mice with allergic airways disease. Allergen sensitization and challenge with multiple doses of either ovalbumin (OVA) or house dust mite (HDM) are performed before HRV infection [4,46,47]. Following OVA sensitization, HRV infection triggers eosinophilic inflammation and airway hyperresponsiveness, along with increased expression of mucins (Muc5AC and Muc5B), eotaxin-1/CCL11, IL-4 and IL-13 $[4,46,47]$. In this model, the major cellular source of CCL11 is surprisingly the activated CD11b+ exudative macrophage (Figure 2) rather than airway epithelial cells [47]. Further, the macrophage plays an indispensable role in eosinophilic infiltration and airway responsiveness in HRV-infected OVA-treated mice [46,47]. Administration of clodronate to deplete macrophages or neutralizing antibody against CCL11 each attenuate HRV-induced airway eosinophilia and responsiveness in OVA-sensitized mice [46,47]. CD11b+ cells from OVA-treated, HRV-infected CD11b-DTR mice show M2 polarization and depletion of CD11b+, IL-13-producing cells in, decreased airway inflammation and responsiveness [126]. HRV colocalizes with CD68+ CD11b+ macrophages following experimental infection in humans, confirming that macrophages play a role in human asthma exacerbations [127]. HRV infection has also been shown to abrogate inhaled OVA-induced tolerance by suppressing the generation of forkhead box protein 3 (Foxp3) + T regulatory (Treg) cells through IL-33, thymic stromal lymphopoietin (TSLP) and OX40 ligand (OX40L) signaling [128]. IL-33 and TSLP, along with IL-25, are epithelial-derived innate cytokines which stimulate production of type 2 cytokines via stimulation 
of Th2 helper cells and type 2 innate lymphoid cells (ILC2s, Figure 2). In addition, HRV infection of HDM-treated mice induces plasmacytoid dendritic cell (pDC) recruitment to the lung and pDC abrogates HRV-induced inflammation. IL-25 was also induced by allergen challenge and HRV infection and conditioned pDCs for pro-inflammatory function [129]. Sputum pDC numbers were also increased during human asthma exacerbations, confirming the value of the mouse model.

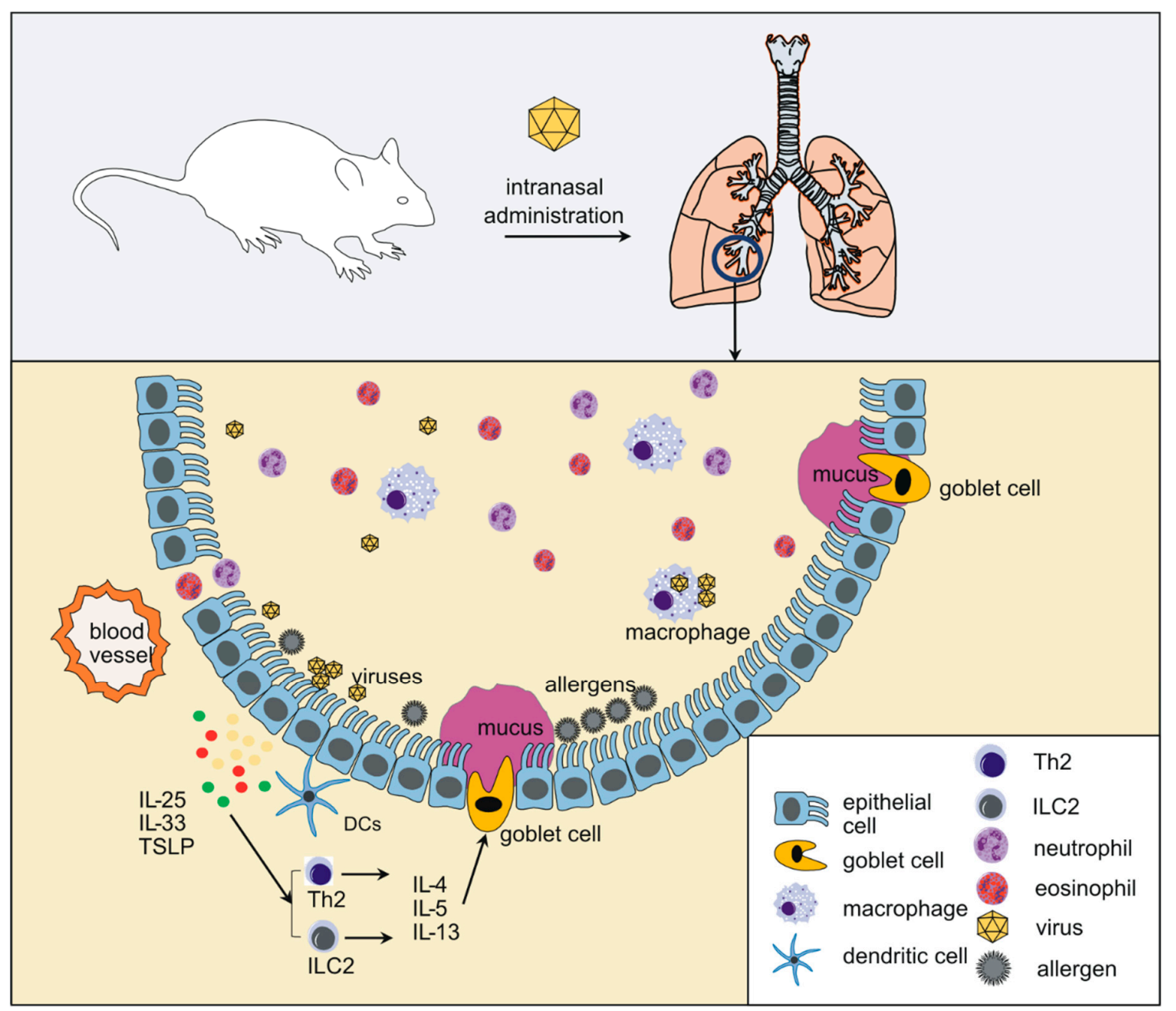

Figure 2. Array of airway cells involved in the response to viral infection. Viruses replicate in the airway epithelium and epithelial cells secrete chemokines which attract innate immune cells to the airway. The airway epithelium also includes resident dendritic cells that respond to allergens, pathogens and damage signals. Among the other innate immune cells shown to be activated after viral infection are exudative macrophages (also called inflammatory monocytes) and innate lymphoid cells. Epithelial-derived innate cytokines (IL-25, IL-33 and TSLP) play a special role as they may activate type 2 helper T (Th2) cells and type 2 innate lymphoid cells (ILC2s) which elaborate type 2 cytokines (IL-4, IL-5 and IL-13) leading to mucous metaplasia. Thus, under certain circumstances, initiation of type 2 inflammation by viruses may not require allergen exposure.

Aeroallergen exposure using HDM has been considered more clinically relevant to HRV infection and asthma exacerbation, as sensitization can be accomplished through the airways [130]. However, different HDM exposure methods may generate inconsistent outcomes. After ten consecutive days of intranasal exposure to $25 \mu \mathrm{g}$ HDM, a classic Th2-driven response was not observed and HRV infection caused additive effects on airway neutrophilic inflammation as well as IgE level and airway responsiveness [130]. On the contrary, in mice receiving intranasal exposure of high-dose HDM at early time points and multiple treatments of low-dose HDM at later time points, HRV triggers both type 1 and type 2 responses including IL-4 and IL-13 expression, eosinophilic inflammation and 
airway hyperresponsiveness [48-50,131]. Using this HDM model, HRV infection triggers neutrophil extracellular traps (NETs)-related dsDNA release which is consistent with experimental human infection [48]. Finally, as an alternative method, dsRNA has been administered to HDM-treated mice to simulate viral-induced asthma exacerbation [128].

\subsection{Models of HRV-Induced Asthma Development in Immature Mice}

Genetic factors and early-life airway exposures to aeroallergens and respiratory viral infections predispose children to asthma development in later life. The immature immune system is qualitatively different from the adult, refractory to type 1 responses but permissive to type 2 responses [132]. Immature mice (younger than 7 days of age) have been used as an age-appropriate model to study virus-mediated chronic immunopathology and asthma development. A delayed and prolonged type 2 immune response which is featured with increased expression of IL-4, IL-5 and IL-13, as well as mucous metaplasia and airways hyperresponsiveness occurs in HRV-infected immature but not in adult mice [53,56]. On the contrary, type 1 response is attenuated in HRV-infected neonatal mice [56,132]. Thus, there is a developmental difference in the response to HRV. IL-13 has been shown to play a role in mucus metaplasia [133] and administration of anti-IL-13 neutralizing antibody can reduce the asthma-like phenotype following early-life HRV infection [53].

The cellular source of IL-13 in HRV-infected immature mice has been determined by flow-cytometry and type 2 innate lymphoid cells (ILC2s), not TCR $\beta+$ cells, are the major cellular source of IL-13 secretion [56]. The requirement and sufficiency of IL-13-expressing ILC2s in the HRV-induced mucous metaplasia phenotype have been proven by administering g SR3335, a chemical inhibitor for ILC2-related transcription factor RAR-related orphan receptor alpha (ROR $\alpha)$ and adoptive transfer of ILC2s to the lung immature and adult recipients, respectively [134]. SR3335 treatment decreases the number of lung ILC2s as well as mucous metaplasia [134]. Adoptive transfer of ILC2s causes mucous metaplasia in both immature and adult mice [134]. Increased expression level of the epithelial-derived innate cytokines IL-25, IL-33 and TSLP is observed in HRV-infected immature mice [55]. Treatment with anti-IL-25 or anti-IL-33 neutralizing antibody, or TSLP receptor (TSLPR) KO attenuates asthma-like phenotype and ILC2 expansion in HRV infected immature mice [55]. Finally, treatment of HRV-infected mice with recombinant IFN- $\gamma$, a classic type 1 cytokine, while not blocking expression of the epithelial-derived innate cytokines, inhibits ILC2 proliferation and activation as well as development of the asthma-like phenotype [132].

\section{Enterovirus D68 (EV-D68)}

\subsection{Virology and EV-D68 Disease}

Since the discovery in California in 1962 from hospitalized children [135], EV-D68 infection has been considered rare until a worldwide upsurge in detection of EV-D68 in the last decade [136-140]. The Morbidity and Mortality Weekly Report (MMWR) in 2011 highlighted EV-D68 as an increasingly recognized cause of respiratory illness, with six clusters of EV-D68 associated respiratory illness reported from Asia, Europe and the United States between 2008-2010 [141]. In 2014, the United States experienced a nationwide EV-D68 respiratory disease outbreak with over 1150 cases reported [142,143]. The epidemiologic study reveals EV-D68-associated respiratory illness was predominantly reported in children with a median age of 5 years, especially in the preschool and school aged children [142]. However, the age of those reported ranged widely from 3 days-92 years. Of note, more than half of children confirmed EV-D68 infection have a prior history of asthma [142,144]. Common symptoms include dyspnea, cough, wheezing and fever. In 2016, 138 cases of EV-D68 were reported to the National Respiratory and Enteric Virus Surveillance System (NREVSS) [145].

In addition to acute respiratory infection, cases of AFM were reported coincident with the 2014 EVD-68 outbreak [146,147]. The paralysis occurred primarily in children and many of them experienced 
respiratory illness before the onset of the limb weakness. A case-control study from the 2014 AFM cases in Colorado suggested an association of EV-D68 [148].

EV-D68 is a non-polio human enterovirus belonging to Group D, the enterovirus genus, whose members are characterized by a small icosahedral viral capsid and with a single positive-stranded RNA genome. EV-D68 strains consist of four major genetic clades A, B, C and recently suggested clade $\mathrm{D}$, as determined by phylogenetic analysis of ${ }^{\prime}$ the VP1 gene $[136,140,149]$. Clade $B$ has three subclades (B1, B2 and B3). EV-D68 shares structural [150] and some biologic features [151] with HRVs. HRV-87 was subsequently identified as a EV strain by molecular diagnosis and antigenic characterization [152-154]. Sialic acid was initially considered important for the EV-D68 entry into the permissive cells with a preference of sialic acid with an $\alpha-2,6$ linkages [155]. However, a later report suggests both $\alpha 2,6$ - and $\alpha 2,3$-lined sialic acid function as cellular EV-D68 receptors and sialic acid-independent EV-D68 variants have been identified [156]. Furthermore, intercellular adhesion molecule 5 (ICAM-5) has recently been identified to be indispensable for the entry of both sialic acid-dependent and independent EV-D68 and soluble ICAM-5 fragment inhibits EV-D68 infection in primary human bronchial epithelial cells, primary rat neurons and mouse brain tissue [8].

\subsection{Animal Models of EV-D68}

The prototype of EV-D68, the Fermon strain, was isolated from the respiratory specimen of pediatric patients with lower respiratory tract illness, indicating its tropism targets the respiratory tract [135]. The ability of EV-D68 to infect the mouse respiratory tract was initially evaluated using cotton rats [11]. Three EV-D68 isolates, the prototype Fermon strain, pre-outbreak isolate VANBT/1 and outbreak isolate US/MO/14-18949, were given through intranasal route with a titer of 106 TCID50. These three isolates showed varied replication ability, with the VANBT/1 isolate showing the most potent replication in both nose and lung. Resembling the mouse model of HRV infection, however, EV-D68 replicated to a limited extent in the rat airway and the infectious virus and amount of negative strand genomic RNA were almost undetectable at $48 \mathrm{~h}$ post-infection. Nasal inoculation of cotton rats with VANBT/1 showed significant induction of pulmonary cytokine mRNA expression (CCL2, CCL5, CXCL1, CXCL10, IL-6, IFN- $\beta$ and IFN- $\gamma$ ) and histologic evidence of peribronchiolitis and alveolitis [11]. In another study using adult BALB/c mice, EV-D68 (US/MO/14-18947 strain) viral RNA was detected in lungs up to 4 days after infection with a gradual decline starting from $12 \mathrm{~h}$ post-infection. Compared with HRV-A1B infection, EV-D68 induced higher IL-17 mRNA and protein, neutrophilic inflammation and airway responsiveness, due to an increased number of IL-17-producing ILC3s and $\gamma \delta$ T cells [9]. Higher nasal IL-17 mRNA levels were confirmed in human patients.

Cotton rat and mouse models for EV-D68 airway infection are asymptomatic. On the other hand, ferrets infected with EV-D68 intranasally show clinical signs of respiratory illness including cough, nasal discharge and dry nose [12]. A large amount of viral RNA was found in the feces, nasal swab, lymph node and lung, while the viral load was low in trachea, bronchoalveolar lavage fluid and blood. No virus was detected from the central nervous system or throat swabs. Interestingly, $\alpha 2,6-$ but not $\alpha 2,3$-linked sialic acid showed intense co-localization with EV-D68 in the ferret lung [12]. Nasal infection of ferrets increased lung protein abundance of IL-1 $\alpha$, IL-5, IL-8, IL-12, IL-13 and IL-17a as well as alveolar inflammation and hemorrhage [12].

\section{Enterovirus-D68 Acute Flaccid Myelitis (AFM) Model}

An immature mouse model has been established to study the correlation between EV-D68 infection and AFM [10]. Five 2014 circulating strains and two prototype strains were used to intracerebrally infect 2 day old mice and four out of five of the 2014 circulating strains led to paralytic disease and/or neonatal death with varied disease rate, time course and mortality. After intracerebral injection of the $\mathrm{MO} / 14-18947$ strain, viral titers in the spinal cord peaked at day 4 and steadily dropped until day 12 post-infection. The onset of paralysis occurred 3-5 days after infection which was coincident with peak viral titer in the spinal cord. The paralysis produced in forelimbs and/or hindlimbs, with the 
former being the most commonly affected [10]. Alternative routes of EV-D68 infection, including intramuscular, intranasal and intraperitoneal infection, also caused paralysis but it was rare and delayed [10]. In a recent study, intraperitoneal infection of one-day-old Institute of Cancer Research (ICR) mice with EV-D68 strains US/MO/14-18947 and US/KY/14-18953 but not Fermon strain, caused limb paralysis and death which was age- and virus dose-dependent [157]. In addition, AG149 interferon receptor deficient mice also showed neurological and muscle disease after intraperitoneal infection of EV-D68 [158].

\subsection{Animal Models of EV-D68 Induced Asthma Exacerbation}

EV-D68 preferentially causes severe respiratory symptoms in children and adults that have a prior history of asthma [142]. Thus, in addition to naïve mice, HDM-sensitized and -challenged mice also been studied [9]. In mice with allergic airways disease, EV-D68 enhances allergen-induced type 2 inflammation with increased expression of lung IL-5, IL-13 and Muc5ac and augmentation of bronchoalveolar lavage fluid eosinophils and airway responsiveness [9].

\section{Human Respiratory Syncytial Virus (RSV)}

\subsection{Virology and RSV Disease}

Human respiratory syncytial virus (RSV) is the major cause of serious respiratory disease in infants and young children, usually manifested as a bronchiolitis with wheezing [159,160]. RSV also produces significant morbidity and mortality in elderly and immune compromised adults. Most infants are infected by 2 years of age, with the incidence of severe disease peaking between 6 weeks and 6 months [161,162]. RSV regularly re-infects older children and adults, causing colds and, in patients with chronic lung disease, exacerbations of asthma or COPD. As noted above, infants experiencing community RSV infection suffer from asthma-type symptoms like cough and wheeze which resolve by 13 years of age $[115,163]$. However, infants with severe RSV bronchiolitis requiring hospitalization may have an increased frequency of asthma in later childhood [164,165].

Human RSV is a member of the Pneumoviridae family, Orthopneumovirus genus, along with closely related Orthopneumoviruses, including bovine RSV, ovine RSV and pneumonia virus of mice (PVM) [166]. Orthopneumoviruses are enveloped viruses with the genome organized with a negative-sense, non-segmented RNA, which is about 15,000 nucleotides in length and encodes for 11 viral proteins. A two-step process is used for RSV entry, a viral glycoprotein-mediated attachment step and a fusion step through binding of the viral fusion protein (F protein) to the receptor nucleolin [167]. In the lower airway, the airway epithelium is the primary infection site and macrophages in the lung may be infected as well [168].

\subsection{Experimental Animal Models of RSV}

RSV was first isolated from a chimpanzee [169] and experimental infection of chimpanzees causes upper respiratory tract disease resembling RSV disease in humans [170]. However, evidence of lower airways disease was not detected. The non-human primate model has been extended to Cebus monkeys [171] and owl monkeys [172] and these models have been mainly used to evaluate vaccine efficacy and study vaccine-related pulmonary pathology (see review [173]). Starting from late 1970's, small animal models of human RSV infection were developed using ferrets [17], cotton rats [14], inbred mice [13] and guinea pigs [15,174] (Tables 1-3).

In guinea pigs, human RSV infection causes acute bronchiolitis without clinical signs and weight loss [15]. Viral antigens appear primarily in the airway epithelium and alveolar macrophage. Interestingly, RSV persistence has been observed in infected lung of guinea pigs up to 60 days [73,174]. RSV infection also increases cytokine expression, lymphocytes, neutrophils, eosinophils and airway hyperresponsiveness occurs in naïve or OVA-sensitized guinea pigs $[175,176]$. In ferrets, human RSV infects both the upper and lower respiratory tracts and triggers production of IL- $1 \alpha$, IL-1 $\beta$, TNF- $\alpha$, 
IFN- $\gamma$, IL-17 and various chemokines [17,177]. Infectious RSV is cleared 9 days after infection [177]. Like guinea pigs, no clinical signs are observed in RSV-infected ferrets [17]. In lungs of RSV-infected ferrets, virus replication is age-dependent with highest titers in the youngest animal [17]. The cotton rat is also permissive for human RSV with a similar viral growth kinetic as the mouse, in which the viral titer peaks at day 4 and declines to undetectable at day 7 [14]. Unlike the ferret, RSV replication in the cotton rat is not age-dependent. Viral antigen primarily appears in the bronchial and bronchiolar epithelium but not trachea and alveolar cells [14]. The cotton rat is a standard model for evaluation of vaccines, antivirals and neutralizing antibodies [178-180].

Non-human orthopneumoviruses/natural host pairs, bovine RSV/calf and PMV/mouse, represent alternative approaches to the study of orthopneumoviruses infections. Besides fully permissive replication in their natural host, infection of bRSV and PMV induce a similar immune cell responses as human RSV infection, such as CD8 +T cells and pro-inflammatory cytokine and chemokine responses [181,182]. The cognate virus models of human RSV have been reviewed extensively by Taylor [173], Sacco et al. [183] and Bem et al. [184].

\subsection{Human RSV Mouse Model}

Compared to other small animal models, the human RSV mouse model has been widely used for the study of pathogenesis as well as vaccine development. This is based on the large pool of available immunological reagents and commercially available transgenic and gene-deleted mice. Long [13] and A2 strains [58] of RSV have been the standard laboratory strains employed to infect mice. In the lung, RSV titers peak on days 4 to 6 post-infection and decline to undetectable at day 11 [58,59]. Infectious virus is recovered from both upper and lower airways [58,60]. To visualize RSV in living mice, recombinant human RSV expressing the firefly luciferase has been constructed using the Long [185] and rA2-line 19F as backbones [186]. Bioluminescence signal has been detected in the nasal cavity and lungs of infected-mice $[185,186]$. In the lower airway, fluorescence staining reveals the presence of viral antigen in the bronchiolar epithelium and alveoli $[58,59,65]$. Perivascular and peribronchial lymphocytes and macrophage infiltrates progressively develop during RSV infection, which is age- and inoculum size-dependent $[59,60]$. Histological lung lesions has been noticed as well [58]. RSV infection can cause visible illness manifested by ruffled fur, reduced activity and weight loss in mice [60].

$\mathrm{BALB} / \mathrm{c}$ is the most common mouse strain used in experimental infections of human RSV (See Table 1). The susceptibility of mice to human RSV is host-strain dependent. Twenty different strains of inbred mice have been screened initially by giving RSV Long strain to 3-day old mice intranasally [13]. Strain-specific differences in RSV susceptibility of immature mice have been observed with the sDBA/2N strain being most susceptible and two common strains, BALB/c and C57BL/6, having intermediate susceptibility [13]. In adult mice, AKR/J was the most permissive strain among eight examined eight strains, while the C57BL/ 6 is the most resistant [57]. F1 progeny from AKR/J and C57BL/ 6 mice inherit RSV resistance from the resistant C57BL/6 parent [57]. A genome-wide association study of disease following human RSV infection in 30 inbred strains of mice identified several potential genetic determinants for RSV susceptibility, including the macrophage receptor with collagenous structure (Marco), an innate immunity scavenger receptor [187]. In addition to genetic determinants, the age dependence of viral replication in the lung has been documented $[58,60]$. RSV replication in the lungs of older mice was significantly greater than younger mice using A2 strain infection $[58,60,188]$, though RSV infection in newborn mice follows the same viral kinetics as in adults with peak viral load at four days post-infection $[13,54,57,61,189,190]$. Sex does not seem to change the susceptibility to RSV infection or viral replication [58].

Mouse models implicate specific subsets of pulmonary immune cells in the development of human RSV disease. Acute RSV infection causes pulmonary cytotoxic responses in the lung with increased populations of natural killer (NK) cells and CD8+ T cells [59,191,192]. CD8+ T and NK cells are involved in pathogen clearance and immunopathology during RSV infection [191,192]. RSV-specific memory 
CD8+ T cells cause lethal immunopathology upon RSV reinfection [193]. In contrast, RSV-specific CD60+/CD103+ tissue resident memory $\mathrm{T}$ cells confer protection against severe respiratory viral disease during RSV reinfection [194-196]. Regulatory T (Treg) cells also reduce the immunopathology and airway inflammation by limiting both innate and adaptive immunity such as suppression of antigen-specific CD8+ T cell responses and maintain Th1/Th2 balance [197-200]. Finally, conventional CD103+ DCs are essential to promote CD8+ T cell responses [201], whereas the plasmacytoid DC and its derived semaphorin 4a are indispensable for Treg expansion during HRSV infection [202].

Human RSV infection has been associated with increased IL-4 expression, suggestive of a type 2 inflammatory response $[203,204]$. However, experimental infection using the human RSV A2 strain does not trigger eosinophilic inflammation or abundant Th2 cytokine expression in adult BALB/c mice, which may be partially due to the function of Treg cells [200] and CD8+ T cells [59,62,205]. Priming the immune response by immunization with a formalin-inactivated human RSV vaccine or sensitization with the RSV attachment glycoprotein (G) augments the Th2 response and promotes pulmonary eosinophilia during RSV infection [63,64]. In these primed adult mice, CD8+ T cells downregulate Th2 pathology by suppressing Th2 cytokine expression and eosinophilic inflammation $[59,62,205]$. IFN- $\gamma$-expressing NK cells precede CD8+ T cells and are essential to recruit CD8+ $\mathrm{T}$ cells in the lung [23]. IL-12 treatment further augments NK cell IFN- $\gamma$ expression which in return inhibits lung eosinophilic inflammation [206].

Different human RSV strains cause different phenotypic responses in adult mice. The Line 19 strain, isolated from the infant patient at the University of Michigan [207], induces significant dose-responsive airway hyperresponsiveness, mucus metaplasia and IL-13 expression in 6-week old BALB/c mice, whereas the A2 and Long strains do not [208-210]. Meanwhile, the expression of the innate cytokines IL-25 and TSLP are increased in Line 19 infected BALB/c mice [211,212]. Anti-IL-25 treatment or TLSPR KO blocks RSV Line 19-induced airway hyperresponsiveness and mucus production [211,212]. No significant viral replication difference between strains A2 and Line 19 has been observed. The fusion (F) gene of Line 19 strain has been identified as a mucogenic virulence factor and a recombinant virus rA2-Line 19F, carrying fusion (F) gene from the Line 19 strain induces airway hyperresponsiveness, mucus metaplasia and IL-13 expression as Line 19 does [209]. Strain-specific pathogenesis has been further confirmed using six different clinical isolates of the RSV antigenic subgroup A [65]. Infection of mature BALB/c mice with the A2001/2-20 isolate causes more weight loss, dyspnea, IL-13 and Gob5 expression, epithelial desquamation, bronchiolitis, mucus metaplasia and airway hyperresponsiveness than the other strains, while showing fewer IFN- $\gamma$ expressing CD8+ T cells, which function to suppress RSV-induced Th2 responses [65]. Interestingly, A2001/2-20 showed several unique features the first day of infection, including significantly higher viral load, the presence of RSV antigen in the bronchiolar epithelium and perivascular edema [65]. Blocking IL-25 signaling attenuates allergic airway inflammation in RSV A2001/2-20-infected mice [211]. As was shown earlier in HRV-infected 6 day-old mice [55,56]. In addition, ILC2s have been determined to be the major early source of IL-13 production in A2001/2-20 infected adult mice, a process which is TSLP and IL-33 dependent [66]. The transcription factor signal transducer and activator of transcription 1 (STAT1) governs ILC2 expansion during A2001/2-20 infection [213].

\subsection{Models of RSV-Induced Asthma Exacerbation in Mice with Allergic Airways Disease}

Allergen sensitization has also been used to study the effects of human RSV on allergic responses and asthma exacerbation [214]. In OVA-sensitized adult mice, RSV infection prolongs airway lymphocytic inflammation, mucus deposition and methacholine-induced airway hyperresponsiveness (but not the number of airway eosinophils) compared to mock infection [214]. Expression of mucus-related genes Muc5ac and Gob-5 is also increased in OVA-treated, RSV-infected mice [215]. Interestingly, OVA-sensitized, RSV-infected mice also show increased expression of IL-17A, which is protective against Th2 allergic responses. Accordingly, IL-17A knockout mice show more IL-13 
production and eosinophil infiltrates [216]. Paradoxically, infection with human RSV decreases house dust mite-induced eosinophils [217].

RSV-induced exacerbation of allergic airways disease has also been studied in mice exposed to cockroach allergen [51,52,218]. In these studies, RSV potentiates cockroach-induced type 2 inflammation. During RSV exacerbation, in vivo neutralization of a specific Notch ligand, Delta-like ligand-4, significantly decreased airway hyperresponsiveness, mucus production and Th2 cytokines [51].

\subsection{Models of Human RSV-Induced Asthma Development in Immature Mice}

Since human RSV infection in early life is suspected to play a role in the development of post-bronchiolitis wheezing and asthma, immature mouse models with mice age ranging from 1 day to three weeks have been used to closely mimic the interaction between RSV and the human infant immune system (see Table 1). During experimental infection, antigen-specific and IFN- $\gamma$ expressing CD4+ and CD8+ T cells are recruited to the lung tissue and airway which peak 8-10 days post-infection $[219,220]$. However, $\mathrm{T}$ cell recruitment in the airway is reduced in RSV-infected immature mice compared to adults [220]. The CD8+ T cell response is also age-dependent and limited in 7-day old mice compared to mice older than 4 weeks [61,188]. Aged mice show a significant reduction in CD8+ T cells in response to RSV infection but cytokine production is preserved [221]. In addition, the epitope hierarchy of neonates is distinct from adults in human RSV-infected mice, with a codominant response against both KdM282-90 and DbM187-195 epitopes in neonates following HRSV infection, compared to an immunodominant response to the KdM282-90 epitope in adult [188]. In immature mice, the CD8+ T cell immunodominance hierarchy has been linked to the role of plasmacytoid DCs [222], which are quantitatively and functionally deficient compared to adults [201]. CD103low DCs, which represent the major fraction of CD103+ plasmacytoid DCs, are phenotypically immature with lower expression of lineage-defining and maturation markers and induce weaker CD8+ T cell specific responses [223].

Aside different cellular responses, a type 2 skewed immune response has been observed in human RSV-infected neonatal mice. Immature mice have shown reduced and delayed IFN- $\gamma$ responses following RSV infection [61,224]. By contrast, compared to 3-weeks old mice, mice less than 1-week old showed more IL-13 expression along with increased number of mucus-producing cells and airway tissue eosinophilia during RSV infection [224]. The recombinant HRSV rA2-Line 19F has been used to optimize the neonatal RSV infection model [54]. Similar to HRV neonatal infection [56], ILC2s are increased following neonatal HRSV infection but not in adult mice, which is in agreement with an age-dependent epithelial-derived IL-33 expression [225].

The immature infection model has also been extended to study recurrent RSV infection. Mouse studies show that the age of initial infection is a risk factor for subsequent RSV-mediated disease. Seven-day old mice infected with human RSV show more severe weight loss, airway hyperresponsiveness and airway inflammation (including neutrophils, eosinophils, CD8+ T cells and type 2 cytokine expression) during RSV re-challenge in adulthood compared with mice undergoing primary infection at four weeks $[61,224,226]$. Major histocompatibility complex (MHC) haplotype, CD4+ T cells, CD8+ T cells, NK cells, macrophages, type 1 IFNs and pDCs all play important roles in the response to reinfection [226-230]. STAT6 inhibitory peptide treatment of young mice at the time of primary RSV infection attenuates the response to RSV reinfection [231].

As noted above, infants experiencing community RSV infection suffer from asthma-type symptoms like cough and wheeze which resolve by 13 years of age $[115,163]$. However, a cohort of Swedish infants with severe RSV bronchiolitis requiring hospitalization later developed asthma which continued into young adulthood $[164,165]$. Young adults also showed increased prevalence of clinical allergy, suggesting that early-life RSV infection could alter responses to allergen exposure. Consistent with this, early-life human RSV infection predisposes mice to enhanced allergic airway disease and Th2 responses to allergen exposure in adulthood [232]. To the contrary, primary RSV infection protects 
adult mice from OVA-induced allergic responses by inhibiting ILC2 [233]. Moreover, repeating RSV infection in OVA-tolerized infant mice impairs Treg function by inducing a Th2-like effector phenotype, resulting in allergic airway disease in response to later OVA exposure [234].

\subsection{PVM Model of Asthma Development}

Like human RSV, PVM is a member of the Pneumoviridae family, Orthopneumovirus genus. Infection of mice with PVM therefore represents a useful model of human RSV infection [18]. Similar to HRV infection [129], there is a marked infiltration of pDC into the airways following PVM infection which is attenuated in TLR7- and MyD88-deficient mice [235]. In another study, cockroach extract-induced IL-33 expression dampened antiviral immunity to subsequent PVM infection [236], providing a mechanism which could predispose asthma patients to more symptomatic viral infections.

\section{Human Metapneumovirus (hMPV)}

\section{1. $h M P V$ Virology and Disease}

First isolated from patients with lower respiratory tract infections in the Netherlands in 2001, hMPV was retrospectively identified in samples collected in the 1950's [237]. Closely related to RSV, hMPV is a member of the Pneumoviridae family, Metapneumovirus Genus. hMPV also causes respiratory infections in human of all ages, primarily in young children and in immunocompromised individuals, with clinical signs of pneumonitis, bronchiolitis and acute wheezing [238-241]. In addition, hMPV infection has rarely been associated with asthma exacerbation in both children and adult $[240,242,243]$. hMPV contains a non-segmented, negative-sense RNA genome approximately 13500 nucleotides in length [244]. The genomic organization for hMPV is similar but not identical to that of RSV. hMPV lacks the non-structural proteins NS1 and NS2 of RSV and the gene order of RSV and hMPV varies significantly [244].

\subsection{Animal Models of hMPV Infection}

Non-human primates and small animal models for hMPV were established immediately after the first identification of hMPV [22,245]. During intranasal infection, hamsters and ferrets are most permissive tor hMPV replication [21,22]. BALB/c mice and the cotton rat have intermediate susceptibility for hMPV infection [21,22]. In the cotton rat, hMPV titer peaks around 4 days after infection and viral antigens are detected exclusively in respiratory epithelial cells [20,21]. hMPV subtype A strain grows better than the subtype B strain in cotton rats [20].

In BALB/c mice, hMPV replication shows a biphasic growth kinetic with two peaks of viral titer at 7 days and 14-28 days after infection [19,67]. Similar to RSV, hMPV can persist in the lung with recovered infectious virus up to 60 days and detectable viral genomic RNA over 180 days [19]. The lung persistence of HMPV has been associated with the HMPV infection of PGP9.5+ neuronal cells [67]. Around the peak time of hMPV replication, infected-mice show clinical symptoms consisting of breathing difficulties, ruffled fur and weight loss [68]. In the airway, hMPV causes increased mucus production, airway hyperresponsiveness and airway obstruction after the primary infection $[19,69,246,247]$. Neutrophil and mononuclear cell infiltration $[19,68]$ as well as increased CD8+ but not CD4+ T cells have been seen in hMPV infected mice [248]. Neutrophil depletion using antibody against Ly6Ghigh neutrophils leads to increased pulmonary inflammation and more severe clinical disease during hMPV infection, even though neutrophils are not associated with hMPV clearance [249]. Depletion was associated with an increase in $\gamma \delta \mathrm{T}$ cells and deficiency of these cells reduced lung pathology, suggesting they play a deleterious role.

$\mathrm{T}$ cell depletion assays suggest that CD4+ and CD8+ T cells cooperate synergistically in hMPV clearance but CD4+ rather than CD8+ T cells efficiently enhance clinical disease and lung pathology during primary infection [250]. hMPV infection increases both Th1 (IFN- $\gamma$ ) and Th2 cytokines, including IL-4 and IL-5 [246-248]. Aging is another important factor affecting hMPV pathogenesis. 
The aged mice showed higher clinical severity which is coincident with attenuated production of virus-specific antibody and IFN- $\gamma$ and increased IL-4 expression [251].

Since hMPV is closely related to human RSV, the pathology and immune responses to the hMPV D03-574 and RSV A2 strains have been directly compared in BALB/c adult mice [252]. hMPV infection causes more severe airway obstruction, weight loss and histopathology. In addition, more neutrophils and activated NK cells were recruited in hMPV-infected mice, which correlated with increased IL-6, TNF- $\alpha$ and CCL2/MCP-1 [252].

Though hMPV infection has been linked to asthma exacerbation, few studies have been performed to elucidate underlying mechanisms. hMPV infection causes eosinophilic and increased Th2 cytokines in mice immunized with the inactivated hMPV [253]. TSLP expression is increased in hMPV infected mice, while TSLPR-/- mice showed reduced airway inflammation as well as inhibited Th2 cytokine expression including IL-5 and IL-13 [254].

\section{Human Parainfluenza Virus (hPIV)}

\section{1. hPIV Virology and Disease}

Within the order Mononegavirales, the Paramyxoviridae family is a large group of viruses that cause significant human and veterinary disease in addition to the Pneumoviridae family [255]. Being members of the family Paramyxoviridae, hPIVs, which are characterized by an enveloped virion and single-stranded negative-sense RNA genome, were first isolated in 1950's in patients with lower respiratory tract disease [256]. hPIVs are genetically and antigenically divided into types 1 to 4 along with further described subgroups or subtypes [257-259]. There are two genera of hPIV, Respirovirus (hPIV-1 and hPIV-3) and Rubulavirus (hPIV-2 and hPIV-4). Mouse Sendai virus (SeV), which is responsible for a highly transmissible respiratory tract infection, is a member of genus Respirovirus.

hPIVs cause both upper and lower respiratory infections with clinical presentations including cough, acute laryngotracheobronchitis (croup), bronchiolitis, tracheobronchitis, pneumonia and, rarely, neurologic disease [260-263]. hPIV-induced respiratory infection contributes to hospitalization in children under age $5[264,265]$. hPIV 1 to 3 are commonly detected, while infants younger than 6 months are particularly vulnerable to hPIV-3 infection [266]. Cases of hPIV4 infection are rare. hPIVs have been detected in asthma patients [267-269] but there are few studies correlating hPIV infection and asthma development or exacerbation.

\subsection{Animal Models of hPIV Infection}

hPIVs infect many different animals both naturally and under experimental conditions. In hamsters and cotton rats, hPIV3 replication peaks within $48 \mathrm{~h}$, with histologic changes including epithelial damage and inflammatory infiltrates [24,26]. Interestingly, histologic changes vary in different cotton rat strains following hPIV infection: Sigmodon hispidus develops bronchiolitis, while Sigmodon fulviventer develops interstitial pneumonia [24]. After experimental infection, hPIV viral antigen appears in bronchial and bronchiolar epithelial cells, macrophages and alveolar type II pneumocytes [24]. hPIV3 also replicates in the larynx and causes laryngotracheitis in the cotton rat [270]. hPIV3 causes fatal disease in newborn ferrets [27,271].

The hPIVs poorly infect mice [272]. Instead, experimental infection with mouse parainfluenza type 1 Sendai Virus (SeV) allows for high viral replication and a pattern of infection and illness that resembles hPIV infection [28,70,71]. The primary infection of SeV in the living mice has been determined using a recombinant $\mathrm{SeV}$ expressing luciferase reporter, [273]. Contact transmission of $\mathrm{SeV}$ leads to robust viral titers in the upper respiratory tract with later spread to the lungs [273]. The primary infection after airborne transmission starts either in the nasopharynx or in the trachea [273]. $\mathrm{SeV}$ antigens are detected in both bronchiolar and alveolar epithelial cells in infected rats and mice $[28,74]$. SeV increases epithelial-derived IL-12 p40 production which is associated with increased mobility and mortality [70]. SeV also targets the macrophage and induces apoptosis during its 
replication [71]. SeV infection causes dose-dependent effects in mice ranging from no effect to reversible bronchiolitis to lethal bronchopneumonia. Inflammatory infiltrates include neutrophils, lymphocytes and monocytes/macrophages $[28,70,274]$. The intercellular adhesion molecule 1 (ICAM-1) has been associated with immune cell recruitment during SeV infection and ICAM-1 deficient mice are protected against acute $\mathrm{SeV}$ infection [28,275]. In addition, the CCL5-CCR5 axis is essential to maintain the viral-clearance function of macrophages and to drive migration of lung conventional DCs to the lymph nodes [71,276].

\subsection{SeV Model of Asthma Development}

After $\mathrm{SeV}$ acute infection of naïve mice, there is a delayed but permanent switch to chronic airway responses which are characterized by airway hyperresponsiveness and chronic goblet cell hyperplasia which develop by 7 weeks of age [28,277]. In these mice, expression of IL-13 and Muc5ac is observed weeks after initial SeV infection. The major cellular source of IL-13 changes from the CD4+ T cell at day 21 after infection to macrophages at 7 weeks after infection [277]. NKT cells and macrophages are required for maximal IL-13 production [277]. Moreover, SeV infection increases type I IFN receptor-dependent expression of FceRI and production of CCL28 on/by mouse lung dendritic cells, leading to recruitment of IL-13-producing Th2 cells [278]. Recent studies also suggests the importance of CD49d+/cysteinyl leukotriene receptor 1 (CysLTR1) + polymorphonuclear neutrophils for FceRI expression on mouse lung DCs and subsequent chronic asthma development [279-281]. In addition, the persistent infection of $\mathrm{SeV}$ in the nerve tissue has been linked to chronic asthma development [282]. In guinea pigs, SeV infection alters vagal afferent innervation in the airways, with increased tachykinin expression in both nociceptive-like and non-nociceptive neurons [30]. $\mathrm{SeV}$ may also cause dysfunction of inhibitory M2 muscarinic receptors on the airway parasympathetic nerves [283].

The effects of early life $\mathrm{SeV}$ infection on later asthma development has also been extensively studied in rats. SeV infection induced necrotizing bronchiolitis and interstitial pneumonia as well as transient airway obstruction and hyperresponsiveness in five day-old, 25 day-old and adult rats $[74,76,284]$. SeV infection in young rats also leads to persistent lung morphologic changes including alveolar dysplasia, bronchiolar hypoplasia and bronchiolar mural fibrosis $[29,75,77,284-286]$. $\mathrm{SeV}$ infection of five and 25 day-old rats causes airway hyperresponsiveness for up to 10 weeks [29,77,285]. The induced asthma-like phenotypes in young rats are strain-dependent [29]. Compared to SeV-infected Brown Norway rats which show increased thickness of bronchiolar wall, persistent pulmonary dysfunction and airway hyperresponsiveness, the Fischer 344 rats are more resistant to virus-induced alternations in pulmonary function abnormalities [29]. In addition, the infected Brown-Norway strain but not the Fischer strain showed a persistent level of IL-13 after early-life SeV infection [287]. Persistent viral infection has been noticed in both infected rat strains and there is no significant difference of viral replication [287]. Young Brown-Norway rats respond differently than Fischer rats to acute $\mathrm{SeV}$ infection, as indicated by lower IFN- $\gamma$ levels in bronchoalveolar lavage fluid, increased expression of TGF- $\beta$ and differential activation of NFKB signaling [29,288-291].

\section{Human Coronavirus (HCoV) and Human Bocaviruses (HBoV)}

Members of the Coronaviridae family, OC43, 229E, NL63 and HKU1, have been associated with self-limiting respiratory tract infections in human. On the other hand, severe acute respiratory syndrome (SARS)-CoV and Middle East respiratory syndrome (MERS)-CoV, cause severe respiratory disease in human. Most animal models have been established for the study of SARS-CoV and MERS-CoV which are less relevant to asthma.

$\mathrm{HBoV}$ was first isolated in 2005 and has been detected in both the respiratory tract and gastrointestinal tract [292-294]. HBoVs belong to the family Parvoviridae, which consists of a group of small non-enveloped single-stranded DNA viruses. HBoV has been found alone in patients with 
respiratory complaints but more often, it is found in combination with other common respiratory viruses such as HRV and RSV [295]. Though the presence of HBoV has been associated with clinical manifestations including rhinorrhea, pneumonia, bronchiolitis, acute wheezing and asthma exacerbation [293,295-297], HBoV pathogenicity remains to be fully clarified mainly due to the lack of animal models. The first trial of HBoV infection in ferret lung has recently been performed [298].

\section{Closing Remarks}

Respiratory viral infections are strongly associated with asthma exacerbations. Further, wheezing associated respiratory viral infections in early life have been linked to asthma development. Investigators have therefore studied human respiratory viral infections in small animals, with the mouse being the predominant species studied.

In this paper we have touched on the difficulties and limitations of animal models for determining pathways of virus-induced asthma. To review and expand on this point, small animals are less permissive to human viruses and usually require a high dose of inoculum for viral respiratory infection, in particular viral replication. The barriers to replication may include differences in viral receptors, mucosal barriers, signaling molecules and other mechanisms. As a result, the kinetics of viral replication and clearance in small animals are often different from natural human infection. In addition, human viral infections in small animals are mostly asymptomatic, which makes clinical correlation difficult. What then, can we learn from small animal models of viral infection?

Certainly, studies of human viral replication and clearance in small animals must be regarded with some hesitation. On the other hand, the inflammatory response driving respiratory viral diseases appears intact in small animals. In contrast to airway epithelial cells which support viral replication, recent data from our lab [47,55,56,124,126,127,134] and others [129,277,299-301] suggest that the inflammatory response to respiratory viral infection in large part arises from and depends on innate immune effector cells, rather than epithelial cells (Figure 2). These include exudative macrophages, innate lymphoid cells, NKT cells and plasmacytoid dendritic cells.

Thus, despite limitations, studies have yielded valuable information about viral pathogenesis and potential mechanisms of asthma exacerbation and development. Recent studies have identified specific roles for epithelial-derived innate cytokines and their cellular targets. In some cases, cell and molecular mediators identified in animal models have been confirmed in human subjects. Further experimentation in mouse models will undoubtedly contribute to the development of new therapeutic interventions for asthma.

Funding: This work was supported by National Institutes of Health Grants R01 AI120526 and R01 HL134369.

Conflicts of Interest: The authors declare no conflicts of interest.

\section{References}

1. Wenzel, S. Severe asthma in adults. Am. J. Respir. Crit. Care Med. 2005, 172, 149-160. [CrossRef] [PubMed]

2. Robinson, D.S.; Hamid, Q.; Ying, S.; Tsicopoulos, A.; Barkans, J.; Bentley, A.M.; Corrigan, C.; Durham, S.R.; Kay, A.B. Predominant TH2-like Bronchoalveolar T-Lymphocyte Population in Atopic Asthma. N. Engl. J. Med. 1992, 326, 298-304. [CrossRef] [PubMed]

3. Woodruff, P.G.; Modrek, B.; Choy, D.F.; Jia, G.; Abbas, A.R.; Ellwanger, A.; Arron, J.R.; Koth, L.L.; Fahy, J.V. T-helper Type 2-driven Inflammation Defines Major Subphenotypes of Asthma. Am. J. Respir. Crit. Care Med. 2009, 180, 388-395. [CrossRef] [PubMed]

4. Bartlett, N.W.; Walton, R.P.; Edwards, M.R.; Aniscenko, J.; Caramori, G.; Zhu, J.; Glanville, N.; Choy, K.J.; Jourdan, P.; Burnet, J.; et al. Mouse models of rhinovirus-induced disease and exacerbation of allergic airway inflammation. Nat. Med. 2008, 14, 199-204. [CrossRef]

5. Newcomb, D.C.; Sajjan, U.S.; Nagarkar, D.R.; Wang, Q.; Nanua, S.; Zhou, Y.; McHenry, C.L.; Hennrick, K.T.; Tsai, W.C.; Bentley, J.K.; et al. Human rhinovirus 1B exposure induces phosphatidylinositol 3-kinase-dependent airway inflammation in mice. Am. J. Respir. Crit. Care Med. 2008, 177, 1111-1121. [CrossRef] [PubMed] 
6. Blanco, J.C.; Core, S.; Pletneva, L.M.; March, T.H.; Boukhvalova, M.S.; Kajon, A.E. Prophylactic Antibody Treatment and Intramuscular Immunization Reduce Infectious Human Rhinovirus 16 Load in the Lower Respiratory Tract of Challenged Cotton Rats. Trials Vaccinol. 2014, 3, 52-60. [CrossRef] [PubMed]

7. Patel, M.C.; Pletneva, L.M.; Boukhvalova, M.S.; Vogel, S.N.; Kajon, A.E.; Blanco, J.C.G. Immunization with Live Human Rhinovirus (HRV) 16 Induces Protection in Cotton Rats against HRV14 Infection. Front. Microbiol. 2017, 8, 1646. [CrossRef]

8. Wei, W.; Guo, H.R.; Chang, J.L.; Yu, Y.Z.; Liu, G.C.; Zhang, N.N.; Willard, S.H.; Zheng, S.; Yu, X.F. ICAM-5/Telencephalin Is a Functional Entry Receptor for Enterovirus D68. Cell Host Microbe 2016, 20, 631-641. [CrossRef]

9. Rajput, C.; Han, M.; Bentley, J.K.; Lei, J.; Ishikawa, T.; Wu, Q.; Hinde, J.L.; Callear, A.P.; Stillwell, T.L.; Jackson, W.T.; et al. Enterovirus D68 infection induces IL-17-dependent neutrophilic airway inflammation and hyperresponsiveness. JCI Insight 2018, 3, 121882. [CrossRef]

10. Hixon, A.M.; Yu, G.; Leser, J.S.; Yagi, S.; Clarke, P.; Chiu, C.Y.; Tyler, K.L. A mouse model of paralytic myelitis caused by enterovirus D68. PLoS Pathog. 2017, 13, e1006199. [CrossRef]

11. Patel, M.C.; Wang, W.; Pletneva, L.M.; Rajagopala, S.V.; Tan, Y.; Hartert, T.V.; Boukhvalova, M.S.; Vogel, S.N.; Das, S.R.; Blanco, J.C. Enterovirus D-68 Infection, Prophylaxis, and Vaccination in a Novel Permissive Animal Model, the Cotton Rat (Sigmodon hispidus). PLoS ONE 2016, 11, e0166336. [CrossRef] [PubMed]

12. Zheng, H.W.; Sun, M.; Guo, L.; Wang, J.J.; Song, J.; Li, J.Q.; Li, H.Z.; Ning, R.T.; Yang, Z.N.; Fan, H.T.; et al. Nasal Infection of Enterovirus D68 Leading to Lower Respiratory Tract Pathogenesis in Ferrets (Mustela putorius furo). Viruses 2017, 9.

13. Prince, G.A.; Horswood, R.L.; Berndt, J.; Suffin, S.C.; Chanock, R.M. Respiratory syncytial virus infection in inbred mice. Infect. Immun. 1979, 26, 764-766. [PubMed]

14. Prince, G.A.; Jenson, A.B.; Horswood, R.L.; Camargo, E.; Chanock, R.M. The pathogenesis of respiratory syncytial virus infection in cotton rats. Am. J. Pathol. 1978, 93, 771-791.

15. Hegele, R.G.; Robinson, P.J.; Gonzalez, S.; Hogg, J.C. Production of acute bronchiolitis in guinea-pigs by human respiratory syncytial virus. Eur. Respir. J. 1993, 6, 1324-1331. [PubMed]

16. Liang, B.; Surman, S.; Amaro-Carambot, E.; Kabatova, B.; Mackow, N.; Lingemann, M.; Yang, L.; McLellan, J.S.; Graham, B.S.; Kwong, P.D.; et al. Enhanced Neutralizing Antibody Response Induced by Respiratory Syncytial Virus Prefusion F Protein Expressed by a Vaccine Candidate. J. Virol. 2015, 89, 9499-9510. [CrossRef]

17. Prince, G.A.; Porter, D.D. The pathogenesis of respiratory syncytial virus infection in infant ferrets. Am. J. Pathol. 1976, 82, 339-352.

18. Dyer, K.D.; Garcia-Crespo, K.E.; Glineur, S.; Domachowske, J.B.; Rosenberg, H.F. The Pneumonia Virus of Mice (PVM) model of acute respiratory infection. Viruses 2012, 4, 3494-3510. [CrossRef]

19. Alvarez, R.; Harrod, K.S.; Shieh, W.J.; Zaki, S.; Tripp, R.A. Human metapneumovirus persists in BALB/c mice despite the presence of neutralizing antibodies. J. Virol. 2004, 78, 14003-14011. [CrossRef]

20. Wyde, P.R.; Chetty, S.N.; Jewell, A.M.; Schoonover, S.L.; Piedra, P.A. Development of a cotton rat-human metapneumovirus (hMPV) model for identifying and evaluating potential hMPV antivirals and vaccines. Antivir. Res. 2005, 66, 57-66. [CrossRef]

21. Williams, J.V.; Tollefson, S.J.; Johnson, J.E.; Crowe, J.E. The cotton rat (Sigmodon hispidus) is a permissive small animal model of human metapneumovirus infection, pathogenesis, and protective immunity. J. Virol. 2005, 79, 10944-10951. [CrossRef] [PubMed]

22. MacPhail, M.; Schickli, J.H.; Tang, R.S.; Kaur, J.; Robinson, C.; Fouchier, R.A.; Osterhaus, A.D.; Spaete, R.R.; Haller, A.A. Identification of small-animal and primate models for evaluation of vaccine candidates for human metapneumovirus (hMPV) and implications for hMPV vaccine design. J. Gen. Virol. 2004, 85, 1655-1663. [CrossRef] [PubMed]

23. Hussell, T.; Openshaw, P.J. Intracellular IFN-gamma expression in natural killer cells precedes lung CD8+ T cell recruitment during respiratory syncytial virus infection. J. Gen. Virol. 1998, 79, 2593-2601. [CrossRef] [PubMed]

24. Porter, D.D.; Prince, G.A.; Hemming, V.G.; Porter, H.G. Pathogenesis of human parainfluenza virus 3 infection in two species of cotton rats: Sigmodon hispidus develops bronchiolitis, while Sigmodon fulviventer develops interstitial pneumonia. J. Virol. 1991, 65, 103-111. [PubMed] 
25. Buckner, C.K.; Clayton, D.E.; Ain-Shoka, A.A.; Busse, W.W.; Dick, E.C.; Shult, P. Parainfluenza 3 infection blocks the ability of a beta adrenergic receptor agonist to inhibit antigen-induced contraction of guinea pig isolated airway smooth muscle. J. Clin. Investig. 1981, 67, 376-384. [CrossRef] [PubMed]

26. Buthala, D.A.; Soret, M.G. Parainfluenza Type 3 Virus Infection in Hamsters: Virologic, Serologic, and Pathologic Studies. J. Infect. Dis. 1964, 114, 226-234. [CrossRef] [PubMed]

27. Metzgar, D.P.; Gower, T.A.; Larson, E.J.; Fuscaldo, A.A.; Mascoli, C.C. Effect of Parainfluenza Virus Type-3 on Newborn Ferrets. J. Biol. Stand. 1974, 2, 273-282. [CrossRef]

28. Walter, M.J.; Morton, J.D.; Kajiwara, N.; Agapov, E.; Holtzman, M.J. Viral induction of a chronic asthma phenotype and genetic segregation from the acute response. J. Clin. Investig. 2002, 110, 165-175. [CrossRef]

29. Uhl, E.W.; Castleman, W.L.; Sorkness, R.L.; Busse, W.W.; Lemanske, R.F., Jr.; McAllister, P.K. Parainfluenza virus-induced persistence of airway inflammation, fibrosis, and dysfunction associated with TGF-beta 1 expression in brown Norway rats. Am. J. Respir. Crit. Care Med. 1996, 154, 1834-1842. [CrossRef]

30. Carr, M.J.; Hunter, D.D.; Jacoby, D.B.; Undem, B.J. Expression of tachykinins in nonnociceptive vagal afferent neurons during respiratory viral infection in guinea pigs. Am. J. Respir. Crit. Care Med. 2002, 165, 1071-1075. [CrossRef]

31. Percy, D.H.; Palmer, D.J. Pathogenesis of Sendai virus infection in the Syrian hamster. Lab. Anim. Sci. 1997, 47, 132-137. [PubMed]

32. Teo, S.M.; Mok, D.; Pham, K.; Kusel, M.; Serralha, M.; Troy, N.; Holt, B.J.; Hales, B.J.; Walker, M.L.; Hollams, E.; et al. The Infant Nasopharyngeal Microbiome Impacts Severity of Lower Respiratory Infection and Risk of Asthma Development. Cell Host Microbe 2015, 17, 704-715. [CrossRef] [PubMed]

33. Jackson, D.J.; Evans, M.D.; Gangnon, R.E.; Tisler, C.J.; Pappas, T.E.; Lee, W.M.; Gern, J.E.; Lemanske, R.F. Evidence for a Causal Relationship between Allergic Sensitization and Rhinovirus Wheezing in Early Life. Am. J. Respir. Crit. Care Med. 2012, 185, 281-285. [CrossRef] [PubMed]

34. Caliskan, M.; Bochkov, Y.A.; Kreiner-Moller, E.; Bonnelykke, K.; Stein, M.M.; Du, G.X.; Bisgaard, H.; Jackson, D.J.; Gern, J.E.; Lemanske, R.F.; et al. Rhinovirus Wheezing Illness and Genetic Risk of Childhood-Onset Asthma. N. Engl. J. Med. 2013, 368, 1398-1407. [CrossRef] [PubMed]

35. Johnston, S.L.; Pattemore, P.K.; Sanderson, G.; Smith, S.; Lampe, F.; Josephs, L.; Symington, P.; O’Toole, S.; Myint, S.H.; Tyrrell, D.A.; et al. Community study of role of viral infections in exacerbations of asthma in 9-11 year old children. BMJ 1995, 310, 1225-1229. [CrossRef] [PubMed]

36. Wark, P.A.; Johnston, S.L.; Moric, I.; Simpson, J.L.; Hensley, M.J.; Gibson, P.G. Neutrophil degranulation and cell lysis is associated with clinical severity in virus-induced asthma. Eur. Respir. J. 2002, 19, 68-75. [CrossRef]

37. Heymann, P.W.; Carper, H.T.; Murphy, D.D.; Platts-Mills, T.A.E.; Patrie, J.; McLaughlin, A.P.; Erwin, E.A.; Shaker, M.S.; Hellems, M.; Peerzada, J.; et al. Viral infections in relation to age, atopy, and season of admission among children hospitalized for wheezing. J. Allergy Clin. Immunol. 2004, 114, 239-247. [CrossRef]

38. Roberts, N.; Al Mubarak, R.; Francisco, D.; Kraft, M.; Chu, H.W. Comparison of paired human nasal and bronchial airway epithelial cell responses to rhinovirus infection and IL-13 treatment. Clin. Transl. Med. 2018, 7, 13. [CrossRef]

39. Terajima, M.; Yamaya, M.; Sekizawa, K.; Okinaga, S.; Suzuki, T.; Yamada, N.; Nakayama, K.; Ohrui, T.; Oshima, T.; Numazaki, Y.; et al. Rhinovirus infection of primary cultures of human tracheal epithelium: Role of ICAM-1 and IL-1beta. Am. J. Physiol. 1997, 273, 749-759. [CrossRef]

40. Proud, D.; Sanders, S.P.; Wiehler, S. Human rhinovirus infection induces airway epithelial cell production of human beta-defensin 2 both in vitro and in vivo. J. Immunol. 2004, 172, 4637-4645. [CrossRef]

41. Gern, J.E.; Dick, E.C.; Lee, W.M.; Murray, S.; Meyer, K.; Handzel, Z.T.; Busse, W.W. Rhinovirus enters but does not replicate inside monocytes and airway macrophages. J. Immunol. 1996, 156, 621-627.

42. Akoto, C.; Davies, D.E.; Swindle, E.J. Mast cells are permissive for rhinovirus replication: Potential implications for asthma exacerbations. Clin. Exp. Allergy 2017, 47, 351-360. [CrossRef] [PubMed]

43. Villenave, R.; Thavagnanam, S.; Sarlang, S.; Parker, J.; Douglas, I.; Skibinski, G.; Heaney, L.G.; McKaigue, J.P.; Coyle, P.V.; Shields, M.D.; et al. In vitro modeling of respiratory syncytial virus infection of pediatric bronchial epithelium, the primary target of infection in vivo. Proc. Natl. Acad. Sci. USA 2012, 109, 5040-5045. [CrossRef] [PubMed] 
44. Proud, D.; Turner, R.B.; Winther, B.; Wiehler, S.; Tiesman, J.P.; Reichling, T.D.; Juhlin, K.D.; Fulmer, A.W.; Ho, B.Y.; Walanski, A.A.; et al. Gene Expression Profiles during In Vivo Human Rhinovirus Infection: Insights into the Host Response. Am. J. Respir. Crit. Care Med. 2008, 178, 962-968. [CrossRef] [PubMed]

45. Yoon, H.J.; Zhu, Z.; Gwaltney, J.M.; Elias, J.A. Rhinovirus Regulation of IL-1 Receptor Antagonist In Vivo and In Vitro: A Potential Mechanism of Symptom Resolution. J. Immunol. 1999, 162, 7461-7469.

46. Schneider, D.; Hong, J.Y.; Bowman, E.R.; Chung, Y.; Nagarkar, D.R.; McHenry, C.L.; Goldsmith, A.M.; Bentley, J.K.; Lewis, T.C.; Hershenson, M.B. Macrophage/epithelial cell CCL2 contributes to rhinovirus-induced hyperresponsiveness and inflammation in a mouse model of allergic airways disease. Am. J. Physiol. Lung Cell. Mol. Physiol. 2013, 304, L162-L169. [CrossRef] [PubMed]

47. Nagarkar, D.R.; Bowman, E.R.; Schneider, D.; Wang, Q.; Shim, J.; Zhao, Y.; Linn, M.J.; McHenry, C.L.; Gosangi, B.; Bentley, J.K.; et al. Rhinovirus infection of allergen-sensitized and -challenged mice induces eotaxin release from functionally polarized macrophages. J. Immunol. 2010, 185, 2525-2535. [CrossRef]

48. Toussaint, M.; Jackson, D.J.; Swieboda, D.; Guedan, A.; Tsourouktsoglou, T.D.; Ching, Y.M.; Radermecker, C.; Makrinioti, H.; Aniscenko, J.; Bartlett, N.W.; et al. Host DNA released by NETosis promotes rhinovirus-induced type-2 allergic asthma exacerbation. Nat. Med. 2017, 23, 681-691. [CrossRef]

49. Collison, A.; Hatchwell, L.; Verrills, N.; Wark, P.A.; de Siqueira, A.P.; Tooze, M.; Carpenter, H.; Don, A.S.; Morris, J.C.; Zimmermann, N.; et al. The E3 ubiquitin ligase midline 1 promotes allergen and rhinovirus-induced asthma by inhibiting protein phosphatase 2A activity. Nat. Med. 2013, 19, 232-237. [CrossRef]

50. Girkin, J.L.; Hatchwell, L.M.; Collison, A.M.; Starkey, M.R.; Hansbro, P.M.; Yagita, H.; Foster, P.S.; Mattes, J. TRAIL signaling is proinflammatory and proviral in a murine model of rhinovirus $1 \mathrm{~B}$ infection. Am. J. Physiol. Lung Cell. Mol. Physiol. 2017, 312, L89-L99. [CrossRef]

51. Mukherjee, S.; Rasky, A.J.; Lundy, P.A.; Kittan, N.A.; Kunkel, S.L.; Maillard, I.P.; Kowalski, P.E.; Kousis, P.C.; Guidos, C.J.; Lukacs, N.W. STAT5-induced lunatic fringe during Th2 development alters delta-like 4-mediated Th2 cytokine production in respiratory syncytial virus-exacerbated airway allergic disease. J. Immunol. 2014, 192, 996-1003. [CrossRef] [PubMed]

52. John, A.E.; Berlin, A.A.; Lukacs, N.W. Respiratory syncytial virus-induced CCL5/RANTES contributes to exacerbation of allergic airway inflammation. Eur. J. Immunol. 2003, 33, 1677-1685. [CrossRef] [PubMed]

53. Schneider, D.; Hong, J.Y.; Popova, A.P.; Bowman, E.R.; Linn, M.J.; McLean, A.M.; Zhao, Y.; Sonstein, J.; Bentley, J.K.; Weinberg, J.B.; et al. Neonatal rhinovirus infection induces mucous metaplasia and airways hyperresponsiveness. J. Immunol. 2012, 188, 2894-2904. [CrossRef]

54. You, D.; Siefker, D.T.; Shrestha, B.; Saravia, J.; Cormier, S.A. Building a better neonatal mouse model to understand infant respiratory syncytial virus disease. Respir. Res. 2015, 16, 91. [CrossRef] [PubMed]

55. Han, M.; Rajput, C.; Hong, J.Y.; Lei, J.; Hinde, J.L.; Wu, Q.; Bentley, J.K.; Hershenson, M.B. The Innate Cytokines IL-25, IL-33, and TSLP Cooperate in the Induction of Type 2 Innate Lymphoid Cell Expansion and Mucous Metaplasia in Rhinovirus-Infected Immature Mice. J. Immunol. 2017, 199, 1308-1318. [CrossRef] [PubMed]

56. Hong, J.Y.; Bentley, J.K.; Chung, Y.T.; Lei, J.; Steenrod, J.M.; Chen, Q.; Sajjan, U.S.; Hershenson, M.B. Neonatal rhinovirus induces mucous metaplasia and airways hyperresponsiveness through IL-25 and type 2 innate lymphoid cells. J. Allergy Clin. Immunol. 2014, 134, 429-439. [CrossRef] [PubMed]

57. Stark, J.M.; McDowell, S.A.; Koenigsknecht, V.; Prows, D.R.; Leikauf, J.E.; Le Vine, A.M.; Leikauf, G.D. Genetic susceptibility to respiratory syncytial virus infection in inbred mice. J. Med. Virol. 2002, 67, 92-100. [CrossRef] [PubMed]

58. Taylor, G.; Stott, E.J.; Hughes, M.; Collins, A.P. Respiratory syncytial virus infection in mice. Infect. Immun. 1984, 43, 649-655. [PubMed]

59. Anderson, J.J.; Norden, J.; Saunders, D.; Toms, G.L.; Scott, R. Analysis of the local and systemic immune responses induced in BALB/c mice by experimental respiratory syncytial virus infection. J. Gen. Virol. 1990, 71, 1561-1570. [CrossRef]

60. Graham, B.S.; Perkins, M.D.; Wright, P.F.; Karzon, D.T. Primary respiratory syncytial virus infection in mice. J. Med. Virol. 1988, 26, 153-162. [CrossRef]

61. Culley, F.J.; Pollott, J.; Openshaw, P.J.M. Age at first viral infection determines the pattern of T cell-mediated disease during reinfection in adulthood. J. Exp. Med. 2002, 196, 1381-1386. [CrossRef] [PubMed] 
62. Hussell, T.; Baldwin, C.J.; O'Garra, A.; Openshaw, P.J.M. CD8(+) T cells control Th2-driven pathology during pulmonary respiratory syncytial virus infection. Eur. J. Immunol. 1997, 27, 3341-3349. [CrossRef] [PubMed]

63. Openshaw, P.J.M.; Clarke, S.L.; Record, F.M. Pulmonary Eosinophilic Response to Respiratory Syncytial Virus-Infection in Mice Sensitized to the Major Surface Glycoprotein-G. Int. Immunol. 1992, 4, 493-500. [CrossRef] [PubMed]

64. Connors, M.; Giese, N.A.; Kulkarni, A.B.; Firestone, C.Y.; Morse, H.C.; Murphy, B.R. Enhanced Pulmonary Histopathology Induced by Respiratory Syncytial Virus (Rsv) Challenge of Formalin-Inactivated Rsv-Immunized Balb/C Mice Is Abrogated by Depletion of Interleukin-4 (Il-4) and Il-10. J. Virol. 1994, 68, 5321-5325. [PubMed]

65. Stokes, K.L.; Chi, M.H.; Sakamoto, K.; Newcomb, D.C.; Currier, M.G.; Huckabee, M.M.; Lee, S.; Goleniewska, K.; Pretto, C.; Williams, J.V.; et al. Differential pathogenesis of respiratory syncytial virus clinical isolates in BALB/c mice. J. Virol. 2011, 85, 5782-5793. [CrossRef] [PubMed]

66. Stier, M.T.; Bloodworth, M.H.; Toki, S.; Newcomb, D.C.; Goleniewska, K.; Boyd, K.L.; Quitalig, M.; Hotard, A.L.; Moore, M.L.; Hartert, T.V.; et al. Respiratory syncytial virus infection activates IL-13-producing group 2 innate lymphoid cells through thymic stromal lymphopoietin. J. Allergy Clin. Immunol. 2016, 138, 814-824. [CrossRef] [PubMed]

67. Liu, Y.R.; Haas, D.L.; Poore, S.; Isakovic, S.; Gahan, M.; Mahalingam, S.; Fu, Z.F.; Tripp, R.A. Human Metapneumovirus Establishes Persistent Infection in the Lungs of Mice and Is Reactivated by Glucocorticoid Treatment. J. Virol. 2009, 83, 6837-6848. [CrossRef]

68. Hamelin, M.E.; Yim, K.; Kuhn, K.H.; Cragin, R.P.; Boukhvalova, M.; Blanco, J.C.G.; Prince, G.A.; Boivin, G. Pathogenesis of human metapneumovirus lung infection in BALB/c mice and cotton rats. J. Virol. 2005, 79, 8894-8903. [CrossRef]

69. Hamelin, M.E.; Prince, G.A.; Gomez, A.M.; Kinkead, R.; Boivin, G. Human metapneumovirus infection induces long-term pulmonary inflammation associated with airway obstruction and hyperresponsiveness in mice. J. Infect. Dis. 2006, 193, 1634-1642. [CrossRef]

70. Walter, M.J.; Kajiwara, N.; Karanja, P.; Castro, M.; Holtzman, M.J. Interleukin 12 p40 production by barrier epithelial cells during airway inflammation. J. Exp. Med. 2001, 193, 339-351. [CrossRef]

71. Tyner, J.W.; Uchida, O.; Kajiwara, N.; Kim, E.Y.; Patel, A.C.; O'Sullivan, M.P.; Walter, M.J.; Schwendener, R.A.; Cook, D.N.; Danoff, T.M.; et al. CCL5-CCR5 interaction provides antiapoptotic signals for macrophage survival during viral infection. Nat. Med. 2005, 11, 1180-1187. [CrossRef]

72. Stephens, R.; Randolph, D.A.; Huang, G.M.; Holtzman, M.J.; Chaplin, D.D. Antigen-nonspecific recruitment of Th2 cells to the lung as a mechanism for viral infection-induced allergic asthma. J. Immunol. 2002, 169, 5458-5467. [CrossRef] [PubMed]

73. Hegele, R.G.; Hayashi, S.; Bramley, A.M.; Hogg, J.C. Persistence of respiratory syncytial virus genome and protein after acute bronchiolitis in guinea pigs. Chest 1994, 105, 1848-1854. [CrossRef] [PubMed]

74. Castleman, W.L.; Brundage-Anguish, L.J.; Kreitzer, L.; Neuenschwander, S.B. Pathogenesis of bronchiolitis and pneumonia induced in neonatal and weanling rats by parainfluenza (Sendai) virus. Am. J. Pathol. 1987, 129, 277-286. [PubMed]

75. Castleman, W.L.; Owens, S.B.; Brundage-Anguish, L.J. Acute and persistent alterations in pulmonary inflammatory cells and airway mast cells induced by Sendai virus infection in neonatal rats. Vet. Pathol. 1989, 26, 18-25. [CrossRef] [PubMed]

76. Sorkness, R.; Clough, J.J.; Castleman, W.L.; Lemanske, R.F., Jr. Virus-induced airway obstruction and parasympathetic hyperresponsiveness in adult rats. Am. J. Respir. Crit. Care Med. 1994, 150, 28-34. [CrossRef] [PubMed]

77. Sorkness, R.; Lemanske, R.F.; Castleman, W.L. Persistent Airway Hyperresponsiveness after Neonatal Viral Bronchiolitis in Rats. J. Appl. Physiol. 1991, 70, 375-383. [CrossRef]

78. Hadfield, A.T.; Lee, W.M.; Zhao, R.; Oliveira, M.A.; Minor, I.; Rueckert, R.R.; Rossmann, M.G. The refined structure of human rhinovirus 16 at 2.15 angstrom resolution: Implications for the viral life cycle. Structure 1997, 5, 427-441. [CrossRef]

79. Stanway, G.; Hughes, P.J.; Mountford, R.C.; Minor, P.D.; Almond, J.W. The Complete Nucleotide-Sequence of a Common Cold Virus-Human Rhinovirus 14. Nucleic Acids Res. 1984, 12, 7859-7875. [CrossRef]

80. Palmenberg, A.C.; Gern, J.E. Classification and Evolution of Human Rhinoviruses. In Rhinoviruses: Methods and Protocols; Jans, D.A., Ghildyal, R., Eds.; Springer: New York, NY, USA, 2015; pp. 1-10. 
81. Greve, J.M.; Davis, G.; Meyer, A.M.; Forte, C.P.; Yost, S.C.; Marior, C.W.; Kamarck, M.E.; Mcclelland, A. The Major Human Rhinovirus Receptor Is Icam-1. Cell 1989, 56, 839-847. [CrossRef]

82. Staunton, D.E.; Merluzzi, V.J.; Rothlein, R.; Barton, R.; Marlin, S.D.; Springer, T.A. A Cell-Adhesion Molecule, Icam-1, Is the Major Surface-Receptor for Rhinoviruses. Cell 1989, 56, 849-853. [CrossRef]

83. Tomassini, J.E.; Graham, D.; Dewitt, C.M.; Lineberger, D.W.; Rodkey, J.A.; Colonno, R.J. Cdna Cloning Reveals That the Major Group Rhinovirus Receptor on Hela-Cells Is Intercellular-Adhesion Molecule-1. Proc. Natl. Acad. Sci. USA 1989, 86, 4907-4911. [CrossRef] [PubMed]

84. Vlasak, M.; Roivainen, M.; Reithmayer, M.; Goesler, I.; Laine, P.; Snyers, L.; Hovi, T.; Blaas, D. The minor receptor group of human rhinovirus (HRV) includes HRV23 and HRV25, but the presence of a lysine in the VP1 HI loop is not sufficient for receptor binding. J. Virol. 2005, 79, 7389-7395. [CrossRef] [PubMed]

85. Lau, S.K.; Yip, C.C.; Woo, P.C.; Yuen, K.Y. Human rhinovirus C: A newly discovered human rhinovirus species. Emerg. Health Threats J. 2010, 3, e2. [CrossRef] [PubMed]

86. Bochkov, Y.A.; Watters, K.; Ashraf, S.; Griggs, T.F.; Devries, M.K.; Jackson, D.J.; Palmenberg, A.C.; Gern, J.E. Cadherin-related family member 3 , a childhood asthma susceptibility gene product, mediates rhinovirus $\mathrm{C}$ binding and replication. Proc. Natl. Acad. Sci. USA 2015, 112, 5485-5490. [CrossRef] [PubMed]

87. Jacobs, S.E.; Lamson, D.M.; St George, K.; Walsh, T.J. Human rhinoviruses. Clin. Microbiol. Rev. 2013, 26, 135-162. [CrossRef] [PubMed]

88. Arruda, E.; Pitkaranta, A.; Witek, T.J.; Doyle, C.A.; Hayden, F.G. Frequency and natural history of rhinovirus infections in adults during autumn. J. Clin. Microbiol. 1997, 35, 2864-2868. [PubMed]

89. Arruda, E.; Boyle, T.R.; Winther, B.; Pevear, D.C.; Gwaltney, J.M.; Hayden, F.G. Localization of Human Rhinovirus Replication in the Upper Respiratory Tract by In Situ Hybridization. J. Infect. Dis. 1995, 171, 1329-1333. [CrossRef] [PubMed]

90. Gern, J.E.; Galagan, D.M.; Jarjour, N.N.; Dick, E.C.; Busse, W.W. Detection of rhinovirus RNA in lower airway cells during experimentally induced infection. Am. J. Respir. Crit. Care Med. 1997, 155, 1159-1161. [CrossRef] [PubMed]

91. Gern, J.E.; Calhoun, W.; Swenson, C.; Shen, G.; Busse, W.W. Rhinovirus infection preferentially increases lower airway responsiveness in allergic subjects. Am. J. Respir. Crit. Care Med. 1997, 155, 1872-1876. [CrossRef]

92. Mosser, A.G.; Vrtis, R.; Burchell, L.; Lee, W.-M.; Dick, C.R.; Weisshaar, E.; Bock, D.; Swenson, C.A.; Cornwell, R.D.; Meyer, K.C.; et al. Quantitative and Qualitative Analysis of Rhinovirus Infection in Bronchial Tissues. Am. J. Respir. Crit. Care Med. 2005, 171, 645-651. [CrossRef] [PubMed]

93. Papadopoulos, N.G.; Bates, P.J.; Bardin, P.G.; Papi, A.; Leir, S.H.; Fraenkel, D.J.; Meyer, J.; Lackie, P.M.; Sanderson, G.; Holgate, S.T.; et al. Rhinoviruses infect the lower airways. J. Infect. Dis. 2000, 181, 1875-1884. [CrossRef] [PubMed]

94. Wos, M.; Sanak, M.; Soja, J.; Olechnowicz, H.; Busse, W.W.; Szczeklik, A. The Presence of Rhinovirus in Lower Airways of Patients with Bronchial Asthma. Am. J. Respir. Crit. Care Med. 2008, 177, 1082-1089. [CrossRef]

95. Mosser, A.G.; Brockman-Schneider, R.; Amineva, S.; Burchell, L.; Sedgwick, J.B.; Busse, W.W.; Gern, J.E. Similar frequency of rhinovirus-infectible cells in upper and lower airway epithelium. J. Infect. Dis. 2002, 185, 734-743. [CrossRef] [PubMed]

96. DeMore, J.P.; Weisshaar, E.H.; Vrtis, R.F.; Swenson, C.A.; Evans, M.D.; Morin, A.; Hazel, E.; Bork, J.A.; Kakumanu, S.; Sorkness, R.; et al. Similar colds in subjects with allergic asthma and nonatopic subjects after inoculation with rhinovirus-16. J. Allergy Clin. Immunol. 2009, 124, 245-252. [CrossRef] [PubMed]

97. Johnston, N.W.; Johnston, S.L.; Duncan, J.M.; Greene, J.M.; Kebadze, T.; Keith, P.K.; Roy, M.; Waserman, S.; Sears, M.R. The September epidemic of asthma exacerbations in children: A search for etiology. J. Allergy Clin. Immunol. 2005, 115, 132-138. [CrossRef] [PubMed]

98. Nicholson, K.G.; Kent, J.; Ireland, D.C. Respiratory viruses and exacerbations of asthma in adults. BMJ 1993, 307, 982-986. [CrossRef]

99. Tan, W.C.; Xiang, X.; Qiu, D.; Ng, T.P.; Lam, S.F.; Hegele, R.G. Epidemiology of respiratory viruses in patients hospitalized with near-fatal asthma, acute exacerbations of asthma, or chronic obstructive pulmonary disease*1. Am. J. Med. 2003, 115, 272-277. [CrossRef] 
100. Green, R.H.; Brightling, C.E.; McKenna, S.; Hargadon, B.; Parker, D.; Bradding, P.; Wardlaw, A.J.; Pavord, I.D. Asthma exacerbations and sputum eosinophil counts: A randomised controlled trial. Lancet 2002, 360, 1715-1721. [CrossRef]

101. Kistler, A.; Avila, P.C.; Rouskin, S.; Wang, D.; Ward, T.; Yagi, S.; Schnurr, D.; Ganem, D.; DeRisi, J.L.; Boushey, H.A. Pan-Viral Screening of Respiratory Tract Infections in Adults with and without Asthma Reveals Unexpected Human Coronavirus and Human Rhinovirus Diversity. J. Infect. Dis. 2007, 196, 817-825. [CrossRef]

102. Harju, T.H.; Leinonen, M.; Nokso-Koivisto, J.; Korhonen, T.; Räty, R.; He, Q.; Hovi, T.; Mertsola, J.; Bloigu, A.; Rytilä, P.; et al. Pathogenic bacteria and viruses in induced sputum or pharyngeal secretions of adults with stable asthma. Thorax 2006, 61, 579-584. [CrossRef] [PubMed]

103. Atmar, R.L.; Guy, E.; Guntupalli, K.K.; Zimmerman, J.L.; Bandi, V.D.; Baxter, B.D.; Greenberg, S.B. Respiratory tract viral infections in inner-city asthmatic adults. Arch. Intern. Med. 1998, 158, 2453-2459. [CrossRef] [PubMed]

104. Khetsuriani, N.; Kazerouni, N.N.; Erdman, D.D.; Lu, X.; Redd, S.C.; Anderson, L.J.; Teague, W.G. Prevalence of viral respiratory tract infections in children with asthma. J. Allergy Clin. Immunol. 2007, 119, 314-321. [CrossRef] [PubMed]

105. Greenberg, S.B.; Allen, M.; Wilson, J.; Atmar, R.L. Respiratory viral infections in adults with and without chronic obstructive pulmonary disease. Am. J. Respir. Crit. Care Med. 2000, 162, 167-173. [CrossRef] [PubMed]

106. Seemungal, T.; Harper-Owen, R.; Bhowmik, A.; Moric, I.; Sanderson, G.; Message, S.; Maccallum, P.; Meade, T.W.; Jeffries, D.J.; Johnston, S.L.; et al. Respiratory Viruses, Symptoms, and Inflammatory Markers in Acute Exacerbations and Stable Chronic Obstructive Pulmonary Disease. Am. J. Respir. Crit. Care Med. 2001, 164, 1618-1623. [CrossRef] [PubMed]

107. Rohde, G.; Wiethege, A.; Borg, I.; Kauth, M.; Bauer, T.T.; Gillissen, A.; Bufe, A.; Schultze-Werninghaus, G. Respiratory viruses in exacerbations of chronic obstructive pulmonary disease requiring hospitalisation: A case-control study. Thorax 2003, 58, 37-42. [CrossRef] [PubMed]

108. Ko, F.W.S.; Ip, M.; Chan, P.K.S.; Fok, J.P.C.; Chan, M.C.H.; Ngai, J.C.; Chan, D.P.S.; Hui, D.S.C. A 1-Year Prospective Study of the Infectious Etiology in Patients Hospitalized with Acute Exacerbations of COPD. Chest 2007, 131, 44-52. [CrossRef]

109. McManus, T.E.; Marley, A.-M.; Baxter, N.; Christie, S.N.; O’Neill, H.J.; Elborn, J.S.; Coyle, P.V.; Kidney, J.C. Respiratory viral infection in exacerbations of COPD. Respir. Med. 2008, 102, 1575-1580. [CrossRef]

110. Kling, S.; Donninger, H.; Williams, Z.; Vermeulen, J.; Weinberg, E.; Latiff, K.; Ghildyal, R.; Bardin, P. Persistence of rhinovirus RNA after asthma exacerbation in children. Clin. Exp. Allergy 2005, 35, 672-678. [CrossRef]

111. Corne, J.M.; Marshall, C.; Smith, S.; Schreiber, J.; Sanderson, G.; Holgate, S.T.; Johnston, S.L. Frequency, severity, and duration of rhinovirus infections in asthmatic and non-asthmatic individuals: A longitudinal cohort study. Lancet 2002, 359, 831-834. [CrossRef]

112. Kotaniemi-Syrjanen, A.; Vainionpaa, R.; Reijonen, T.M.; Waris, M.; Korhonen, K.; Korppi, M. Rhinovirus-induced wheezing in infancy-the first sign of childhood asthma? J. Allergy Clin. Immunol. 2003, 111, 66-71. [CrossRef] [PubMed]

113. Lemanske, R.F., Jr.; Jackson, D.J.; Gangnon, R.E.; Evans, M.D.; Li, Z.; Shult, P.A.; Kirk, C.J.; Reisdorf, E.; Roberg, K.A.; Anderson, E.L.; et al. Rhinovirus illnesses during infancy predict subsequent childhood wheezing. J. Allergy Clin. Immunol. 2005, 116, 571-577. [CrossRef] [PubMed]

114. Jackson, D.J.; Gangnon, R.E.; Evans, M.D.; Roberg, K.A.; Anderson, E.L.; Pappas, T.E.; Printz, M.C.; Lee, W.M.; Shult, P.A.; Reisdorf, E.; et al. Wheezing rhinovirus illnesses in early life predict asthma development in high-risk children. Am. J. Respir. Crit. Care Med. 2008, 178, 667-672. [CrossRef] [PubMed]

115. Rubner, F.J.; Jackson, D.J.; Evans, M.D.; Gangnon, R.E.; Tisler, C.J.; Pappas, T.E.; Gern, J.E.; Lemanske, R.F. Early life rhinovirus wheezing, allergic sensitization, and asthma risk at adolescence. J. Allergy Clin. Immunol. 2017, 139, 501-507. [CrossRef] [PubMed]

116. Harris, J.R.; Racaniello, V.R. Changes in rhinovirus protein $2 \mathrm{C}$ allow efficient replication in mouse cells. J. Virol. 2003, 77, 4773-4780. [CrossRef] [PubMed] 
117. Tuthill, T.J.; Papadopoulos, N.G.; Jourdan, P.; Challinor, L.J.; Sharp, N.A.; Plumpton, C.; Shah, K.; Barnard, S.; Dash, L.; Burnet, J.; et al. Mouse respiratory epithelial cells support efficient replication of human rhinovirus. J. Gen. Virol. 2003, 84, 2829-2836. [CrossRef] [PubMed]

118. Reithmayer, M.; Reischl, A.; Snyers, L.; Blaas, D. Species-specific receptor recognition by a minor-group human rhinovirus (HRV): HRV serotype 1A distinguishes between the murine and the human low-density lipoprotein receptor. J. Virol. 2002, 76, 6957-6965. [CrossRef]

119. Rasmussen, A.L.; Racaniello, V.R. Selection of rhinovirus $1 \mathrm{~A}$ variants adapted for growth in mouse lung epithelial cells. Virology 2011, 420, 82-88. [CrossRef]

120. Foxman, E.F.; Storer, J.A.; Fitzgerald, M.E.; Wasik, B.R.; Hou, L.; Zhao, H.Y.; Turner, P.E.; Pyle, A.M.; Iwasaki, A. Temperature-dependent innate defense against the common cold virus limits viral replication at warm temperature in mouse airway cells. Proc. Natl. Acad. Sci. USA 2015, 112, 827-832. [CrossRef]

121. Nagarkar, D.R.; Wang, Q.; Shim, J.; Zhao, Y.; Tsai, W.C.; Lukacs, N.W.; Sajjan, U.; Hershenson, M.B. CXCR2 Is Required for Neutrophilic Airway Inflammation and Hyperresponsiveness in a Mouse Model of Human Rhinovirus Infection. J. Immunol. 2009, 183, 6698-6707. [CrossRef]

122. Wang, Q.; Miller, D.J.; Bowman, E.R.; Nagarkar, D.R.; Schneider, D.; Zhao, Y.; Linn, M.J.; Goldsmith, A.M.; Bentley, J.K.; Sajjan, U.S.; et al. MDA5 and TLR3 Initiate Pro-Inflammatory Signaling Pathways Leading to Rhinovirus-Induced Airways Inflammation and Hyperresponsiveness. PLoS Pathog. 2011, 7, e1002070. [CrossRef] [PubMed]

123. Girkin, J.; Hatchwell, L.; Foster, P.; Johnston, S.L.; Bartlett, N.; Collison, A.; Mattes, J. CCL7 and IRF-7 Mediate Hallmark Inflammatory and IFN Responses following Rhinovirus 1B Infection. J. Immunol. 2015, 194, 4924-4930. [CrossRef] [PubMed]

124. Han, M.; Chung, Y.; Young Hong, J.; Rajput, C.; Lei, J.; Hinde, J.L.; Chen, Q.; Weng, S.P.; Bentley, J.K.; Hershenson, M.B. Toll-like receptor 2-expressing macrophages are required and sufficient for rhinovirus-induced airway inflammation. J. Allergy Clin. Immunol. 2016, 138, 1619-1630. [CrossRef] [PubMed]

125. Glanville, N.; Peel, T.J.; Schroder, A.; Aniscenko, J.; Walton, R.P.; Finotto, S.; Johnston, S.L. Tbet Deficiency Causes T Helper Cell Dependent Airways Eosinophilia and Mucus Hypersecretion in Response to Rhinovirus Infection. PLoS Pathog. 2016, 12, e1005913. [CrossRef] [PubMed]

126. Chung, Y.; Hong, J.Y.; Lei, J.; Chen, Q.; Bentley, J.K.; Hershenson, M.B. Rhinovirus Infection Induces IL-13 Production from CD11b-positive, Exudative M2-polarized Exudative Macrophages. Am. J. Respir. Cell Mol. Biol. 2015, 52, 205-216. [CrossRef] [PubMed]

127. Bentley, J.K.; Sajjan, U.S.; Dzaman, M.B.; Jarjour, N.N.; Lee, W.M.; Gern, J.E.; Hershenson, M.B. Rhinovirus colocalizes with CD68- and CD11b-positive macrophages following experimental infection in humans. J. Allergy Clin. Immunol. 2013, 132, 758-761. [CrossRef] [PubMed]

128. Mehta, A.K.; Duan, W.; Doerner, A.M.; Traves, S.L.; Broide, D.H.; Proud, D.; Zuraw, B.L.; Croft, M. Rhinovirus infection interferes with induction of tolerance to aeroantigens through OX40 ligand, thymic stromal lymphopoietin, and IL-33. J. Allergy Clin. Immunol. 2016, 137, 278-288. [CrossRef] [PubMed]

129. Chairakaki, A.-D.; Saridaki, M.-I.; Pyrillou, K.; Mouratis, M.-A.; Koltsida, O.; Walton, R.P.; Bartlett, N.W.; Stavropoulos, A.; Boon, L.; Rovina, N.; et al. Plasmacytoid dendritic cells drive acute asthma exacerbations. J. Allergy Clin. Immunol. 2018, 142, 542-556. [CrossRef]

130. Phan, J.A.; Kicic, A.; Berry, L.J.; Fernandes, L.B.; Zosky, G.R.; Sly, P.D.; Larcombe, A.N. Rhinovirus exacerbates house-dust-mite induced lung disease in adult mice. PLoS ONE 2014, 9, e92163. [CrossRef]

131. Hatchwell, L.; Collison, A.; Girkin, J.; Parsons, K.; Li, J.Y.; Zhang, J.; Phipps, S.; Knight, D.; Bartlett, N.W.; Johnston, S.L.; et al. Toll-like receptor 7 governs interferon and inflammatory responses to rhinovirus and is suppressed by IL-5-induced lung eosinophilia. Thorax 2015, 70, 854-861. [CrossRef]

132. Han, M.; Hong, J.Y.; Jaipalli, S.; Rajput, C.; Lei, J.; Hinde, J.L.; Chen, Q.; Hershenson, N.M.; Bentley, J.K.; Hershenson, M.B. IFN-gamma Blocks Development of an Asthma Phenotype in Rhinovirus-Infected Baby Mice by Inhibiting Type 2 Innate Lymphoid Cells. Am. J. Respir. Cell Mol. Biol. 2017, 56, 242-251. [PubMed]

133. Lachowicz-Scroggins, M.E.; Boushey, H.A.; Finkbeiner, W.E.; Widdicombe, J.H. Interleukin-13-Induced Mucous Metaplasia Increases Susceptibility of Human Airway Epithelium to Rhinovirus Infection. Am. J. Respir. Cell Mol. Biol. 2010, 43, 652-661. [CrossRef] [PubMed] 
134. Rajput, C.; Cui, T.; Han, M.Y.; Lei, J.; Hinde, J.L.; Wu, Q.; Bentley, J.K.; Hershenson, M.B. ROR alpha-dependent type 2 innate lymphoid cells are required and sufficient for mucous metaplasia in immature mice. Am. J. Physiol. Lung Cell. Mol. Physiol. 2017, 312, L983-L993. [CrossRef] [PubMed]

135. Schieble, J.H.; Fox, V.L.; Lennette, E.H. A probable new human picornavirus associated with respiratory diseases. Am. J. Epidemiol. 1967, 85, 297-310. [CrossRef] [PubMed]

136. Tokarz, R.; Firth, C.; Madhi, S.A.; Howie, S.R.C.; Wu, W.; Sall, A.A.; Haq, S.; Briese, T.; Lipkin, W.I. Worldwide emergence of multiple clades of enterovirus 68. J. Gen. Virol. 2012, 93, 1952-1958. [CrossRef] [PubMed]

137. Ikeda, T.; Mizuta, K.; Abiko, C.; Aoki, Y.; Itagaki, T.; Katsushima, F.; Katsushima, Y.; Matsuzaki, Y.; Fuji, N.; Imamura, T.; et al. Acute respiratory infections due to enterovirus 68 in Yamagata, Japan between 2005 and 2010. Microbiol. Immunol. 2012, 56, 139-143. [CrossRef]

138. Lu, Q.B.; Wo, Y.; Wang, H.Y.; Wei, M.T.; Zhang, L.; Yang, H.; Liu, E.M.; Li, T.Y.; Zhao, Z.T.; Liu, W.; et al. Detection of enterovirus 68 as one of the commonest types of enterovirus found in patients with acute respiratory tract infection in China. J. Med. Microbiol. 2014, 63, 408-414. [CrossRef]

139. Meijer, A.; Benschop, K.S.; Donker, G.A.; van der Avoort, H.G. Continued seasonal circulation of enterovirus D68 in the Netherlands, 2011-2014. Eurosurveillance 2014, 19, 2-7. [CrossRef]

140. Meijer, A.; van der Sanden, S.; Snijders, B.E.P.; Jaramillo-Gutierrez, G.; Bont, L.; van der Ent, C.K.; Overduin, P.; Jenny, S.L.; Jusic, E.; van der Avoort, H.G.A.M.; et al. Emergence and epidemic occurrence of enterovirus 68 respiratory infections in The Netherlands in 2010. Virology 2012, 423, 49-57. [CrossRef]

141. Imamura, T.; Suzuki, A.; Meijer, A.; Niesters, H.G.M.; Rahamat-Langendoen, J.C.; Lojo, J.; Hodinka, R.L.; Coffin, S.; Ostroff, S.M.; Kraft, C.S.; et al. Clusters of Acute Respiratory Illness Associated with Human Enterovirus 68-Asia, Europe, and United States, 2008-2010 (Reprinted from MMWR, vol 60, pg 1301-1304, 2011). JAMA J. Am. Med. Assoc. 2011, 306, 1971-1973.

142. Midgley, C.M.; Watson, J.T.; Nix, W.A.; Curns, A.T.; Rogers, S.L.; Brown, B.A.; Conover, C.; Dominguez, S.R.; Feikin, D.R.; Gray, S.; et al. Severe respiratory illness associated with a nationwide outbreak of enterovirus D68 in the USA (2014): A descriptive epidemiological investigation. Lancet Respir. Med. 2015, 3, 879-887. [CrossRef]

143. Messacar, K.; Abzug, M.J.; Dominguez, S.R. 2014 outbreak of enterovirus D68 in North America. J. Med. Virol. 2016, 88, 739-745. [CrossRef]

144. Rao, S.; Messacar, K.; Torok, M.R.; Rick, A.M.; Holzberg, J.; Montano, A.; Bagdure, D.; Curtis, D.J.; Oberste, M.S.; Nix, W.A.; et al. Enterovirus D68 in Critically Ill Children: A Comparison with Pandemic H1N1 Influenza. Pediatr. Crit. Care Med. 2016, 17, 1023-1031. [CrossRef]

145. Abedi, G.R.; Watson, J.T.; Nix, W.A.; Oberste, M.S.; Gerber, S.I. Enterovirus and Parechovirus Surveillance-United States, 2014-2016. MMWR Morb. Mortal. Wkly. Rep. 2018, 67, 515-518. [CrossRef] [PubMed]

146. Leshem, E. Acute Flaccid Myelitis among Persons Aged $<=21$ Years-United States, August 1-November 13, 2014. MMWR Morb. Mortal. Wkly. Rep. 2015, 63, 1243-1244.

147. Greninger, A.L.; Naccache, S.N.; Messacar, K.; Clayton, A.; Yu, G.X.; Somasekar, S.; Federman, S.; Stryke, D.; Anderson, C.; Yagi, S.; et al. A novel outbreak enterovirus D68 strain associated with acute flaccid myelitis cases in the USA (2012-14): A retrospective cohort study. Lancet Infect. Dis. 2015, 15, 671-682. [CrossRef]

148. Aliabadi, N.; Messacar, K.; Pastula, D.M.; Robinson, C.C.; Leshem, E.; Sejvar, J.J.; Nix, W.A.; Oberste, M.S.; Feikin, D.R.; Dominguez, S.R. Enterovirus D68 Infection in Children with Acute Flaccid Myelitis, Colorado, USA, 2014. Emerg. Infect. Dis. 2016, 22, 1387-1394. [CrossRef]

149. Du, J.; Zheng, B.; Zheng, W.; Li, P.; Kang, J.; Hou, J.; Markham, R.; Zhao, K.; Yu, X.F. Analysis of Enterovirus 68 Strains from the 2014 North American Outbreak Reveals a New Clade, Indicating Viral Evolution. PLoS ONE 2015, 10, e0144208. [CrossRef] [PubMed]

150. Liu, Y.; Sheng, J.; Fokine, A.; Meng, G.; Shin, W.H.; Long, F.; Kuhn, R.J.; Kihara, D.; Rossmann, M.G. Structure and inhibition of EV-D68, a virus that causes respiratory illness in children. Science 2015, 347, 71-74. [CrossRef]

151. Oberste, M.S.; Maher, K.; Schnurr, D.; Flemister, M.R.; Lovchik, J.C.; Peters, H.; Sessions, W.; Kirk, C.; Chatterjee, N.; Fuller, S.; et al. Enterovirus 68 is associated with respiratory illness and shares biological features with both the enteroviruses and the rhinoviruses. J. Gen. Virol. 2004, 85, 2577-2584. [CrossRef] 
152. Savolainen, C.; Blomqvist, S.; Mulders, M.N.; Hovi, T. Genetic clustering of all 102 human rhinovirus prototype strains: Serotype 87 is close to human enterovirus 70. J. Gen. Virol. 2002, 83, 333-340. [CrossRef] [PubMed]

153. Ishiko, H.; Miura, R.; Shimada, Y.; Hayashi, A.; Nakajima, H.; Yamazaki, S.; Takeda, N. Human Rhinovirus 87 Identified as Human Enterovirus 68 by VP4-Based Molecular Diagnosis. Intervirology 2002, 45, 136-141. [CrossRef] [PubMed]

154. Blomqvist, S.; Savolainen, C.; Raman, L.; Roivainen, M.; Hovi, T. Human rhinovirus 87 and enterovirus 68 represent a unique serotype with rhinovirus and enterovirus features. J. Clin. Microbiol. 2002, 40, 4218-4223. [CrossRef] [PubMed]

155. Liu, Y.; Sheng, J.; Baggen, J.; Meng, G.; Xiao, C.; Thibaut, H.J.; van Kuppeveld, F.J.; Rossmann, M.G. Sialic acid-dependent cell entry of human enterovirus D68. Nat. Commun. 2015, 6, 8865. [CrossRef] [PubMed]

156. Baggen, J.; Thibaut, H.J.; Staring, J.; Jae, L.T.; Liu, Y.; Guo, H.; Slager, J.J.; de Bruin, J.W.; van Vliet, A.L.; Blomen, V.A.; et al. Enterovirus D68 receptor requirements unveiled by haploid genetics. Proc. Natl. Acad. Sci. USA 2016, 113, 1399-1404. [CrossRef] [PubMed]

157. Zhang, C.; Zhang, X.; Dai, W.; Liu, Q.; Xiong, P.; Wang, S.; Geng, L.; Gong, S.; Huang, Z. A Mouse Model of Enterovirus D68 Infection for Assessment of the Efficacy of Inactivated Vaccine. Viruses 2018, 10, 58. [CrossRef] [PubMed]

158. Morrey, J.D.; Wang, H.; Hurst, B.L.; Zukor, K.; Siddharthan, V.; Van Wettere, A.J.; Sinex, D.G.; Tarbet, E.B. Causation of Acute Flaccid Paralysis by Myelitis and Myositis in Enterovirus-D68 Infected Mice Deficient in Interferon/Receptor Deficient Mice. Viruses 2018, 10, 33. [CrossRef] [PubMed]

159. McIntosh, K.; Ellis, E.F.; Hoffman, L.S.; Lybass, T.G.; Eller, J.J.; Fulginiti, V.A. The association of viral and bacterial respiratory infections with exacerbations of wheezing in young asthmatic children. J. Pediatr. 1973, 82, 578-590. [CrossRef]

160. Glezen, P.; Denny, F.W. Epidemiology of acute lower respiratory disease in children. N. Engl. J. Med. 1973, 288, 498-505. [CrossRef]

161. Leader, S.; Kohlhase, K. Recent trends in severe respiratory syncytial virus (RSV) among US infants, 1997 to 2000. J. Pediatr. 2003, 143, S127-S132. [CrossRef]

162. Glezen, W.P.; Taber, L.H.; Frank, A.L.; Kasel, J.A. Risk of Primary Infection and Reinfection with Respiratory Syncytial Virus. Am. J. Dis. Child. 1986, 140, 543-546. [CrossRef] [PubMed]

163. Stein, R.; Sherrill, D.; Morgan, W.J.; Holberg, C.J.; Halonen, M.; Taussig, L.M.; Wright, A.L.; Martinez, F.D. Respiratory syncytial virus in early life and risk of wheeze and allergy by age 13 years. Lancet 1999, 354, 541-545. [CrossRef]

164. Sigurs, N.; Bjarnason, R.; Sigurbergsson, F.; Kjellman, B. Respiratory syncytial virus bronchiolitis in infancy is an important risk factor for asthma and allergy at age 7. Am. J. Respir. Crit. Care Med. 2000, 161, 1501-1507. [CrossRef] [PubMed]

165. Sigurs, N.; Gustafsson, P.M.; Bjarnason, R.; Lundberg, F.; Schmidt, S.; Sigurbergsson, F.; Kjellman, B. Severe respiratory syncytial virus bronchiolitis in infancy and asthma and allergy at age 13. Am. J. Respir. Crit. Care Med. 2005, 171, 137-141. [CrossRef] [PubMed]

166. Rima, B.; Collins, P.; Easton, A.; Fouchier, R.; Kurath, G.; Lamb, R.A.; Lee, B.; Maisner, A.; Rota, P.; Wang, L.F.; et al. ICTV Virus Taxonomy Profile: Pneumoviridae. J. Gen. Virol. 2017, 98, 2912-2913. [CrossRef] [PubMed]

167. Tayyari, F.; Marchant, D.; Moraes, T.J.; Duan, W.M.; Mastrangelo, P.; Hegele, R.G. Identification of nucleolin as a cellular receptor for human respiratory syncytial virus. Nat. Med. 2011, 17, 1132-1135. [CrossRef] [PubMed]

168. Cirino, N.M.; Panuska, J.R.; Villani, A.; Taraf, H.; Rebert, N.A.; Merolla, R.; Tsivitse, P.; Gilbert, I.A. Restricted Replication of Respiratory Syncytial Virus in Human Alveolar Macrophages. J. Gen. Virol. 1993, 74, 1527-1537. [CrossRef]

169. Blount, R.E., Jr.; Morris, J.A.; Savage, R.E. Recovery of cytopathogenic agent from chimpanzees with coryza. Proc. Soc. Exp. Biol. Med. 1956, 92, 544-549.

170. Belshe, R.B.; Richardson, L.S.; London, W.T.; Sly, D.L.; Lorfeld, J.H.; Camargo, E.; Prevar, D.A.; Chanock, R.M. Experimental respiratory syncytial virus infection of four species of primates. J. Med. Virol. 1977, 1, 157-162. [CrossRef]

171. Richardson, L.S.; Belshe, R.B.; Sly, D.L.; London, W.T.; Prevar, D.A.; Camargo, E.; Chanock, R.M. Experimental respiratory syncytial virus pneumonia in cebus monkeys. J. Med. Virol. 1978, 2, 45-59. [CrossRef] 
172. Richardson, L.S.; Belshe, R.B.; London, W.T.; Sly, D.L.; Prevar, D.A.; Camargo, E.; Chanock, R.M. Evaluation of five temperature-sensitive mutants of respiratory syncytial virus in primates: I. Viral shedding, immunologic response, and associated illness. J. Med. Virol. 1978, 3, 91-100. [CrossRef] [PubMed]

173. Taylor, G. Animal models of respiratory syncytial virus infection. Vaccine 2017, 35, 469-480. [CrossRef] [PubMed]

174. Dakhama, A.; Vitalis, T.Z.; Hegele, R.G. Persistence of respiratory syncytial virus (RSV) infection and development of RSV-specific IgG1 response in a guinea-pig model of acute bronchiolitis. Eur. Respir. J. 1997, 10, 20-26. [CrossRef] [PubMed]

175. Bramley, A.M.; Khan, M.A.; Manson, H.E.; Hegele, R.G. Development of respiratory syncytial virus "bronchiolitis" in guinea pigs does not reflect an allergic predisposition in the host. Chest 2003, 124, 671-681. [CrossRef] [PubMed]

176. Robinson, P.J.; Hegele, R.G.; Schellenberg, R.R. Allergic sensitization increases airway reactivity in guinea pigs with respiratory syncytial virus bronchiolitis. J. Allergy Clin. Immunol. 1997, 100, 492-498. [CrossRef]

177. Chan, K.F.; Carolan, L.A.; Druce, J.; Chappell, K.; Watterson, D.; Young, P.; Korenkov, D.; Subbarao, K.; Barr, I.G.; Laurie, K.L.; et al. Pathogenesis, Humoral Immune Responses, and Transmission between Cohoused Animals in a Ferret Model of Human Respiratory Syncytial Virus Infection. J. Virol. 2018, 92, e01322-17. [CrossRef]

178. Prince, G.A.; Hemming, V.G.; Horswood, R.L.; Baron, P.A.; Chanock, R.M. Effectiveness of topically administered neutralizing antibodies in experimental immunotherapy of respiratory syncytial virus infection in cotton rats. J. Virol. 1987, 61, 1851-1854.

179. Cullen, L.M.; Blanco, J.C.G.; Morrison, T.G. Cotton rat immune responses to virus-like particles containing the pre-fusion form of respiratory syncytial virus fusion protein. J. Transl. Med. 2015, 13, 350. [CrossRef]

180. Stobart, C.C.; Rostad, C.A.; Ke, Z.L.; Dillard, R.S.; Hampton, C.M.; Strauss, J.D.; Yi, H.; Hotard, A.L.; Meng, J.; Pickles, R.J.; et al. A live RSV vaccine with engineered thermostability is immunogenic in cotton rats despite high attenuation. Nat. Commun. 2016, 7, 13916. [CrossRef]

181. Horsfall, F.L.; Hahn, R.G. A Latent Virus in Normal Mice Capable of Producing Pneumonia in Its Natural Host. J. Exp. Med. 1940, 71, 391-408. [CrossRef]

182. Taylor, G.; Thomas, L.H.; Wyld, S.G.; Furze, J.; Sopp, P.; Howard, C.J. Role of T-lymphocyte subsets in recovery from respiratory syncytial virus infection in calves. J. Virol. 1995, 69, 6658-6664. [PubMed]

183. Sacco, R.E.; Durbin, R.K.; Durbin, J.E. Animal models of respiratory syncytial virus infection and disease. Curr. Opin. Virol. 2015, 13, 117-122. [CrossRef] [PubMed]

184. Bem, R.A.; Domachowske, J.B.; Rosenberg, H.F. Animal models of human respiratory syncytial virus disease. Am. J. Physiol. Lung Cell. Mol. Physiol. 2011, 301, L148-L156. [CrossRef] [PubMed]

185. Rameix-Welti, M.A.; Le Goffic, R.; Herve, P.L.; Sourimant, J.; Remot, A.; Riffault, S.; Yu, Q.; Galloux, M.; Gault, E.; Eleouet, J.F. Visualizing the replication of respiratory syncytial virus in cells and in living mice. Nat. Commun. 2014, 5, 5104. [CrossRef] [PubMed]

186. Fuentes, S.; Arenas, D.; Moore, M.M.; Golding, H.; Khurana, S. Development of bioluminescence imaging of respiratory syncytial virus (RSV) in virus-infected live mice and its use for evaluation of therapeutics and vaccines. Vaccine 2017, 35, 694-702. [CrossRef] [PubMed]

187. High, M.; Cho, H.Y.; Marzec, J.; Wiltshire, T.; Verhein, K.C.; Caballero, M.T.; Acosta, P.L.; Ciencewicki, J.; Mccaw, Z.R.; Kobzik, L.; et al. Determinants of host susceptibility to murine respiratory syncytial virus (RSV) disease identify a role for the innate immunity scavenger receptor MARCO gene in human infants. Ebiomedicine 2016, 11, 73-84. [CrossRef] [PubMed]

188. Ruckwardt, T.J.; Malloy, A.M.W.; Gostick, E.; Price, D.A.; Dash, P.; McClaren, J.L.; Thomas, P.G.; Graham, B.S. Neonatal CD8 T-cell Hierarchy Is Distinct from Adults and Is Influenced by Intrinsic T cell Properties in Respiratory Syncytial Virus Infected Mice. PLoS Pathog. 2011, 7, e1002377. [CrossRef]

189. Cormier, S.A.; You, D.H.; Honnegowda, S. The use of a neonatal mouse model to study respiratory syncytial virus infections. Expert Rev. Anti-Infect. Ther. 2010, 8, 1371-1380. [CrossRef]

190. Empey, K.M.; Orend, J.G.; Peebles, R.S.; Egana, L.; Norris, K.A.; Oury, T.D.; Kolls, J.K. Stimulation of Immature Lung Macrophages with Intranasal Interferon Gamma in a Novel Neonatal Mouse Model of Respiratory Syncytial Virus Infection. PLoS ONE 2012, 7, e40499. [CrossRef]

191. Li, F.A.; Zhu, H.Q.; Sun, R.; Wei, H.M.; Tian, Z.G. Natural Killer Cells Are Involved in Acute Lung Immune Injury Caused by Respiratory Syncytial Virus Infection. J. Virol. 2012, 86, 2251-2258. [CrossRef] 
192. Liu, J.; Haddad, E.K.; Marceau, J.; Morabito, K.M.; Rao, S.S.; Filali-Mouhim, A.; Sekaly, R.P.; Graham, B.S. A Numerically Subdominant CD8 T Cell Response to Matrix Protein of Respiratory Syncytial Virus Controls Infection with Limited Immunopathology. PLoS Pathog. 2016, 12, e1005486. [CrossRef] [PubMed]

193. Schmidt, M.E.; Knudson, C.J.; Hartwig, S.M.; Pewe, L.L.; Meyerholz, D.K.; Langlois, R.A.; Harty, J.T.; Varga, S.M. Memory CD8 T cells mediate severe immunopathology following respiratory syncytial virus infection. PLoS Pathog. 2018, 14, e1006810. [CrossRef] [PubMed]

194. Kinnear, E.; Lambert, L.; McDonald, J.U.; Cheeseman, H.M.; Caproni, L.J.; Tregoning, J.S. Airway T cells protect against RSV infection in the absence of antibody. Mucosal Immunol. 2018, 11, 249-256. [CrossRef] [PubMed]

195. Jozwik, A.; Habibi, M.S.; Paras, A.; Zhu, J.; Guvenel, A.; Dhariwal, J.; Almond, M.; Wong, E.H.C.; Sykes, A.; Maybeno, M.; et al. RSV-specific airway resident memory CD8+T cells and differential disease severity after experimental human infection. Nat. Commun. 2015, 6, 10224. [CrossRef] [PubMed]

196. Zhang, L.; Li, H.Y.; Hai, Y.; Yin, W.; Li, W.J.; Zheng, B.Y.; Du, X.M.; Li, N.; Zhang, Z.Z.; Deng, Y.Q.; et al. CpG in Combination with an Inhibitor of Notch Signaling Suppresses Formalin-Inactivated Respiratory Syncytial Virus-Enhanced Airway Hyperresponsiveness and Inflammation by Inhibiting Th17 Memory Responses and Promoting Tissue-Resident Memory Cells in Lungs. J. Virol. 2017, 91, e02111-16. [CrossRef] [PubMed]

197. Fulton, R.B.; Meyerholz, D.K.; Varga, S.M. Foxp3(+) CD4 Regulatory T Cells Limit Pulmonary Immunopathology by Modulating the CD8 T Cell Response during Respiratory Syncytial Virus Infection. J. Immunol. 2010, 185, 2382-2392. [CrossRef] [PubMed]

198. Ruckwardt, T.J.; Bonaparte, K.L.; Nason, M.C.; Graham, B.S. Regulatory T Cells Promote Early Influx of CD8(+) T Cells in the Lungs of Respiratory Syncytial Virus-Infected Mice and Diminish Immunodominance Disparities. J. Virol. 2009, 83, 3019-3028. [CrossRef] [PubMed]

199. Lee, D.C.P.; Harker, J.A.E.; Tregoning, J.S.; Atabani, S.F.; Johansson, C.; Schwarze, J.; Openshaw, P.J.M. CD25(+) Natural Regulatory T Cells Are Critical in Limiting Innate and Adaptive Immunity and Resolving Disease following Respiratory Syncytial Virus Infection. J. Virol. 2010, 84, 8790-8798. [CrossRef]

200. Durant, L.R.; Makris, S.; Voorburg, C.M.; Loebbermann, J.; Johansson, C.; Openshaw, P.J. Regulatory T cells prevent Th2 immune responses and pulmonary eosinophilia during respiratory syncytial virus infection in mice. J. Virol. 2013, 87, 10946-10954. [CrossRef]

201. Ruckwardt, T.J.; Malloy, A.M.W.; Morabito, K.M.; Graham, B.S. Quantitative and Qualitative Deficits in Neonatal Lung-Migratory Dendritic Cells Impact the Generation of the CD8+T Cell Response. PLoS Pathog. 2014, 10, e1003934. [CrossRef]

202. Lynch, J.P.; Werder, R.B.; Loh, Z.X.; Sikder, M.A.; Curren, B.; Zhang, V.V.; Rogers, M.J.; Lane, K.; Simpson, J.; Mazzone, S.B.; et al. Plasmacytoid dendritic cells protect from viral bronchiolitis and asthma through semaphorin 4a-mediated T reg expansion. J. Exp. Med. 2018, 215, 537-557. [CrossRef] [PubMed]

203. Roman, M.; Calhoun, W.J.; Hinton, K.L.; Avendano, L.F.; Simon, V.; Escobar, A.M.; Gaggero, A.; Diaz, P.V. Respiratory syncytial virus infection in infants is associated with predominant Th-2-like response. Am. J. Respir. Crit. Care Med. 1997, 156, 190-195. [CrossRef] [PubMed]

204. Pala, P.; Bjarnason, R.; Sigurbergsson, F.; Metcalfe, C.; Sigurs, N.; Openshaw, P.J.M. Enhanced IL-4 responses in children with a history of respiratory syncytial virus bronchiolitis in infancy. Eur. Respir. J. 2002, 20, 376-382. [CrossRef] [PubMed]

205. Srikiatkhachorn, A.; Braciale, T.J. Virus-specific CD8+ T lymphocytes downregulate T helper cell type 2 cytokine secretion and pulmonary eosinophilia during experimental murine respiratory syncytial virus infection. J. Exp. Med. 1997, 186, 421-432. [CrossRef] [PubMed]

206. Hussell, T.; Openshaw, P.J. IL-12-activated NK cells reduce lung eosinophilia to the attachment protein of respiratory syncytial virus but do not enhance the severity of illness in CD8 T cell-immunodeficient conditions. J. Immunol. 2000, 165, 7109-7115. [CrossRef] [PubMed]

207. Herlocher, M.L.; Ewasyshyn, M.; Sambhara, S.; Gharaee-Kermani, M.; Cho, D.; Lai, J.; Klein, M.; Maassab, H.F. Immunological properties of plaque purified strains of live attenuated respiratory syncytial virus (RSV) for human vaccine. Vaccine 1999, 17, 172-181. [CrossRef]

208. Lukacs, N.W.; Moore, M.L.; Rudd, B.D.; Berlin, A.A.; Collins, R.D.; Olson, S.J.; Ho, S.B.; Peebles, R.S., Jr. Differential immune responses and pulmonary pathophysiology are induced by two different strains of respiratory syncytial virus. Am. J. Pathol. 2006, 169, 977-986. [CrossRef] 
209. Moore, M.L.; Chi, M.H.; Luongo, C.; Lukacs, N.W.; Polosukhin, V.V.; Huckabee, M.M.; Newcomb, D.C.; Buchholz, U.J.; Crowe, J.E., Jr.; Goleniewska, K.; et al. A chimeric A2 strain of respiratory syncytial virus (RSV) with the fusion protein of RSV strain line 19 exhibits enhanced viral load, mucus, and airway dysfunction. J. Virol. 2009, 83, 4185-4194. [CrossRef]

210. Fujimura, K.E.; Demoor, T.; Rauch, M.; Faruqi, A.A.; Jang, S.; Johnson, C.C.; Boushey, H.A.; Zoratti, E.; Ownby, D.; Lukacs, N.W.; et al. House dust exposure mediates gut microbiome Lactobacillus enrichment and airway immune defense against allergens and virus infection. Proc. Natl. Acad. Sci. USA 2014, 111, 805-810. [CrossRef]

211. Petersen, B.C.; Dolgachev, V.; Rasky, A.; Lukacs, N.W. IL-17E (IL-25) and IL-17RB promote respiratory syncytial virus-induced pulmonary disease. J. Leukoc. Biol. 2014, 95, 809-815. [CrossRef]

212. Lee, H.C.; Headley, M.B.; Loo, Y.M.; Berlin, A.; Gale, M.; Debley, J.S.; Lukacs, N.W.; Ziegler, S.F. Thymic stromal lymphopoietin is induced by respiratory syncytial virus-infected airway epithelial cells and promotes a type 2 response to infection. J. Allergy Clin. Immunol. 2012, 130, 1187-1196. [CrossRef]

213. Stier, M.T.; Goleniewska, K.; Cephus, J.Y.; Newcomb, D.C.; Sherrill, T.P.; Boyd, K.L.; Bloodworth, M.H.; Moore, M.L.; Chen, K.; Kolls, J.K.; et al. STAT1 Represses Cytokine-Producing Group 2 and Group 3 Innate Lymphoid Cells during Viral Infection. J. Immunol. 2017, 199, 510-519. [CrossRef]

214. Peebles, R.S.; Sheller, J.R.; Johnson, J.E.; Mitchell, D.B.; Graham, B.S. Respiratory syncytial virus infection prolongs methacholine-induced airway hyperresponsiveness in ovalbumin-sensitized mice. J. Med. Virol. 1999, 57, 186-192. [CrossRef]

215. Hashimoto, K.; Graham, B.S.; Ho, S.B.; Adler, K.B.; Collins, R.D.; Olson, S.J.; Zhou, W.; Suzutani, T.; Jones, P.W.; Goleniewska, K.; et al. Respiratory syncytial virus in allergic lung inflammation increases Muc5ac and gob-5. Am. J. Respir. Crit. Care Med. 2004, 170, 306-312. [CrossRef]

216. Newcomb, D.C.; Boswell, M.G.; Reiss, S.; Zhou, W.; Goleniewska, K.; Toki, S.; Harintho, M.T.; Lukacs, N.W.; Kolls, J.K.; Peebles, R.S., Jr. IL-17A inhibits airway reactivity induced by respiratory syncytial virus infection during allergic airway inflammation. Thorax 2013, 68, 717-723. [CrossRef] [PubMed]

217. Mori, H.; Parker, N.S.; Rodrigues, D.; Hulland, K.; Chappell, D.; Hincks, J.S.; Bright, H.; Evans, S.M.; Lamb, D.J. Differences in respiratory syncytial virus and influenza infection in a house-dust-mite-induced asthma mouse model: Consequences for steroid sensitivity. Clin. Sci. 2013, 125, 565-574. [CrossRef] [PubMed]

218. Lukacs, N.W.; Tekkanat, K.K.; Berlin, A.; Hogaboam, C.M.; Miller, A.; Evanoff, H.; Lincoln, P.; Maassab, H. Respiratory syncytial virus predisposes mice to augmented allergic airway responses via IL-13-mediated mechanisms. J. Immunol. 2001, 167, 1060-1065. [CrossRef]

219. Knudson, C.J.; Weiss, K.A.; Hartwig, S.M.; Varga, S.M. The Pulmonary Localization of Virus-Specific T Lymphocytes Is Governed by the Tissue Tropism of Infection. J. Virol. 2014, 88, 9010-9016. [CrossRef]

220. Eichinger, K.M.; Kosanovich, J.L.; Empey, K.M. Localization of the T-cell response to RSV infection is altered in infant mice. Pediatr. Pulmonol. 2018, 53, 145-153. [CrossRef]

221. Fulton, R.B.; Weiss, K.A.; Pewe, L.L.; Harty, J.T.; Varga, S.M. Aged Mice Exhibit a Severely Diminished CD8 T Cell Response following Respiratory Syncytial Virus Infection. J. Virol. 2013, 87, 12694-12700. [CrossRef]

222. Malloy, A.M.; Ruckwardt, T.J.; Morabito, K.M.; Lau-Kilby, A.W.; Graham, B.S. Pulmonary Dendritic Cell Subsets Shape the Respiratory Syncytial Virus-Specific CD8+ T Cell Immunodominance Hierarchy in Neonates. J. Immunol. 2017, 198, 394-403. [CrossRef] [PubMed]

223. Ruckwardt, T.J.; Morabito, K.M.; Bar-Haim, E.; Nair, D.; Graham, B.S. Neonatal mice possess two phenotypically and functionally distinct lung-migratory CD103(+) dendritic cell populations following respiratory infection. Mucosal Immunol. 2018, 11, 186-198. [CrossRef] [PubMed]

224. Dakhama, A.; Park, J.W.; Taube, C.; Joetham, A.; Balhorn, A.; Miyahara, N.; Takeda, K.; Gelfand, E.W. The enhancement or prevention of airway hyperresponsiveness during reinfection with respiratory syncytial virus is critically dependent on the age at first infection and IL-13 production. J. Immunol. 2005, 175, 1876-1883. [CrossRef] [PubMed]

225. Saravia, J.; You, D.; Shrestha, B.; Jaligama, S.; Siefker, D.; Lee, G.I.; Harding, J.N.; Jones, T.L.; Rovnaghi, C.; Bagga, B.; et al. Respiratory Syncytial Virus Disease Is Mediated by Age-Variable IL-33. PLoS Pathog. 2015, 11, e1005217. [CrossRef] [PubMed] 
226. Harker, J.A.; Yamaguchi, Y.; Culley, F.J.; Tregoning, J.S.; Openshaw, P.J.M. Delayed Sequelae of Neonatal Respiratory Syncytial Virus Infection Are Dependent on Cells of the Innate Immune System. J. Virol. 2014, 88, 604-611. [CrossRef]

227. Tregoning, J.S.; Yamaguchi, Y.; Harker, J.; Wang, B.; Openshaw, P.J.M. The role of T cells in the enhancement of respiratory syncytial virus infection severity during adult reinfection of neonatally sensitized mice. J. Virol. 2008, 82, 4115-4124. [CrossRef]

228. Pribul, P.K.; Harker, J.; Wang, B.; Wang, H.; Tregoning, J.S.; Schwarze, J.; Openshaw, P.J. Alveolar macrophages are a major determinant of early responses to viral lung infection but do not influence subsequent disease development. J. Virol. 2008, 82, 4441-4448. [CrossRef]

229. Tregoning, J.S.; Yamaguchi, Y.; Wang, B.; Mihm, D.; Harker, J.A.; Bushell, E.S.C.; Zheng, M.; Liao, G.C.; Peltz, G.; Openshaw, P.J.M. Genetic Susceptibility to the Delayed Sequelae of Neonatal Respiratory Syncytial Virus Infection Is MHC Dependent. J. Immunol. 2010, 185, 5384-5391. [CrossRef]

230. Cormier, S.A.; Shrestha, B.; Saravia, J.; Lee, G.I.; Shen, L.; DeVincenzo, J.P.; Kim, Y.I.; You, D.H. Limited Type I Interferons and Plasmacytoid Dendritic Cells during Neonatal Respiratory Syncytial Virus Infection Permit Immunopathogenesis upon Reinfection. J. Virol. 2014, 88, 9350-9360. [CrossRef]

231. Srinivasa, B.T.; Restori, K.H.; Shan, J.C.; Cyr, L.; Xing, L.; Lee, S.; Ward, B.J.; Fixman, E.D. STAT6 inhibitory peptide given during RSV infection of neonatal mice reduces exacerbated airway responses upon adult reinfection. J. Leukoc. Biol. 2017, 101, 519-529. [CrossRef]

232. You, D.H.; Becnel, D.; Wang, K.; Ripple, M.; Daly, M.; Cormier, S.A. Exposure of neonates to Respiratory Syncytial Virus is critical in determining subsequent airway response in adults. Respir. Res. 2006, 7, 107. [CrossRef] [PubMed]

233. Wang, D.; Bai, S.; Cui, Y.; Zhao, N.; Qi, F.; Liu, J.; Zeng, S.; Xu, L.; Hu, H.; Liu, B. Respiratory syncytial virus prevents the subsequent development of ovalbumin-induced allergic responses by inhibiting ILC2 via the IL-33/ST2 pathway. Immunotherapy 2018, 10, 1065-1076. [CrossRef] [PubMed]

234. Krishnamoorthy, N.; Khare, A.; Oriss, T.B.; Raundhal, M.; Morse, C.; Yarlagadda, M.; Wenzel, S.E.; Moore, M.L.; Peebles, R.S.; Ray, A.; et al. Early infection with respiratory syncytial virus impairs regulatory $\mathrm{T}$ cell function and increases susceptibility to allergic asthma. Nat. Med. 2012, 18, 1525-1530. [CrossRef] [PubMed]

235. Davidson, S.; Kaiko, G.; Loh, Z.; Lalwani, A.; Zhang, V.; Spann, K.; Foo, S.Y.; Hansbro, N.; Uematsu, S.; Akira, S.; et al. Plasmacytoid dendritic cells promote host defense against acute pneumovirus infection via the TLR7-MyD88-dependent signaling pathway. J. Immunol. 2011, 186, 5938-5948. [CrossRef] [PubMed]

236. Lynch, J.P.; Werder, R.B.; Simpson, J.; Loh, Z.; Zhang, V.; Haque, A.; Spann, K.; Sly, P.D.; Mazzone, S.B.; Upham, J.W.; et al. Aeroallergen-induced IL-33 predisposes to respiratory virus-induced asthma by dampening antiviral immunity. J. Allergy Clin. Immunol. 2016, 138, 1326-1337. [CrossRef] [PubMed]

237. Van den Hoogen, B.G.; de Jong, J.C.; Groen, J.; Kuiken, T.; de Groot, R.; Fouchier, R.A.; Osterhaus, A.D. A newly discovered human pneumovirus isolated from young children with respiratory tract disease. Nat. Med. 2001, 7, 719-724. [CrossRef] [PubMed]

238. Jartti, T.; van den Hoogen, B.; Garofalo, R.P.; Osterhaus, A.D.; Ruuskanen, O. Metapneumovirus and acute wheezing in children. Lancet 2002, 360, 1393-1394. [CrossRef]

239. Boivin, G.; Abed, Y.; Pelletier, G.; Ruel, L.; Moisan, D.; Cote, S.; Peret, T.C.T.; Erdman, D.D.; Anderson, L.J. Virological features and clinical manifestations associated with human metapneumovirus: A new paramyxovirus responsible for acute respiratory-tract infections in all age groups. J. Infect. Dis. 2002, 186, 1330-1334. [CrossRef] [PubMed]

240. Van den Hoogen, B.G.; van Doornum, G.J.J.; Fockens, J.C.; Cornelissen, J.J.; Beyer, W.E.P.; de Groot, R.; Osterhaus, A.D.M.E.; Fouchier, R.A.M. Prevalence and clinical symptoms of human metapneumovirus infection in hospitalized patients. J. Infect. Dis. 2003, 188, 1571-1577. [CrossRef] [PubMed]

241. Falsey, A.R.; Erdman, D.; Anderson, L.J.; Walsh, E.E. Human metapneumovirus infections in young and elderly adults. J. Infect. Dis. 2003, 187, 785-790. [CrossRef] [PubMed]

242. Williams, J.V.; Crowe, J.E., Jr.; Enriquez, R.; Minton, P.; Peebles, R.S., Jr.; Hamilton, R.G.; Higgins, S.; Griffin, M.; Hartert, T.V. Human metapneumovirus infection plays an etiologic role in acute asthma exacerbations requiring hospitalization in adults. J. Infect. Dis. 2005, 192, 1149-1153. [CrossRef] [PubMed] 
243. Williams, J.V.; Harris, P.A.; Tollefson, S.J.; Halburnt-Rush, L.L.; Pingsterhaus, J.M.; Edwards, K.M.; Wright, P.F.; Crowe, J.E. Human metapneumovirus and lower respiratory tract disease in otherwise healthy infants and children. N. Engl. J. Med. 2004, 350, 443-450. [CrossRef] [PubMed]

244. Van den Hoogen, B.G.; Bestebroer, T.M.; Osterhaus, A.D.M.E.; Fouchier, R.A.M. Analysis of the genomic sequence of a human metapneumovirus. Virology 2002, 295, 119-132. [CrossRef]

245. Kuiken, T.; van den Hoogen, B.G.; van Riel, D.A.; Laman, J.D.; van Amerongen, G.; Sprong, L.; Fouchier, R.A.; Osterhaus, A.D. Experimental human metapneumovirus infection of cynomolgus macaques (Macaca fascicularis) results in virus replication in ciliated epithelial cells and pneumocytes with associated lesions throughout the respiratory tract. Am. J. Pathol. 2004, 164, 1893-1900. [CrossRef]

246. Alvarez, R.; Tripp, R.A. The immune response to human metapneumovirus is associated with aberrant immunity and impaired virus clearance in BALB/c mice. J. Virol. 2005, 79, 5971-5978. [CrossRef] [PubMed]

247. Darniot, M.; Petrella, T.; Aho, S.; Pothier, P.; Manoha, C. Immune response and alteration of pulmonary function after primary human metapneumovirus (hMPV) infection of BALB/c mice. Vaccine 2005, 23, 4473-4480. [CrossRef]

248. Herd, K.A.; Nelson, M.; Mahalingam, S.; Tindle, R.W. Pulmonary infection of mice with human metapneumovirus induces local cytotoxic T-cell and immunoregulatory cytokine responses similar to those seen with human respiratory syncytial virus. J. Gen. Virol. 2010, 91, 1302-1310. [CrossRef]

249. Cheemarla, N.R.; Banos-Lara, M.D.; Naidu, S.; Guerrero-Plata, A. Neutrophils regulate the lung inflammatory response via gamma delta $\mathrm{T}$ cell infiltration in an experimental mouse model of human metapneumovirus infection. J. Leukoc. Biol. 2017, 101, 1383-1392. [CrossRef]

250. Kolli, D.; Bataki, E.L.; Spetch, L.; Guerrero-Plata, A.; Jewell, A.M.; Piedra, P.A.; Milligan, G.N.; Garofalo, R.P.; Casola, A. T lymphocytes contribute to antiviral immunity and pathogenesis in experimental human metapneumovirus infection. J. Virol. 2008, 82, 8560-8569. [CrossRef]

251. Darniot, M.; Pitoiset, C.; Petrella, T.; Aho, S.; Pothier, P.; Manoha, C. Age-Associated Aggravation of Clinical Disease after Primary Metapneumovirus Infection of BALB/c Mice. J. Virol. 2009, 83, 3323-3332. [CrossRef]

252. Huck, B.; Neumann-Haefelin, D.; Schmitt-Graeff, A.; Weckmann, M.; Mattes, J.; Ehl, S.; Falcone, V. Human metapneumovirus induces more severe disease and stronger innate immune response in BALB/c mice as compared with respiratory syncytial virus. Respir. Res. 2007, 8, 6. [CrossRef] [PubMed]

253. Hamelin, M.E.; Couture, C.; Sackett, M.K.; Boivin, G. Enhanced lung disease and Th2 response following human metapneumovirus infection in mice immunized with the inactivated virus. J. Gen. Virol. 2007, 88, 3391-3400. [CrossRef] [PubMed]

254. Lay, M.K.; Céspedes, P.F.; Palavecino, C.E.; León, M.A.; Díaz, R.A.; Salazar, F.J.; Méndez, G.P.; Bueno, S.M.; Kalergis, A.M. Human metapneumovirus infection activates the TSLP pathway that drives excessive pulmonary inflammation and viral replication in mice. Eur. J. Immunol. 2015, 45, 1680-1695. [CrossRef] [PubMed]

255. Amarasinghe, G.K.; Bao, Y.; Basler, C.F.; Bavari, S.; Beer, M.; Bejerman, N.; Blasdell, K.R.; Bochnowski, A.; Briese, T.; Bukreyev, A.; et al. Taxonomy of the order Mononegavirales: Update 2017. Arch. Virol. 2017, 162, 2493-2504. [CrossRef] [PubMed]

256. Chanock, R.M.; Parrott, R.H.; Cook, K.; Andrews, B.E.; Bell, J.A.; Reichelderfer, T.; Kapikian, A.Z.; Mastrota, F.M.; Huebner, R.J. Newly recognized myxoviruses from children with respiratory disease. N. Engl. J. Med. 1958, 258, 207-213. [CrossRef] [PubMed]

257. Canchola, J.; Christmann, E.; Kim, H.W.; Parrott, R.H.; Chanock, R.M.; Vargosko, A.J.; Jeffries, B. Antigenic Variation among Newly Isolated Strains of Parainfluenza Type 4 Virus. Am. J. Hyg. 1964, 79, 357-364. [PubMed]

258. Henrickson, K.J.; Savatski, L.L. Two distinct human parainfluenza virus type 1 genotypes detected during the 1991 Milwaukee epidemic. J. Clin. Microbiol. 1996, 34, 695-700.

259. Prinoski, K.; Cote, M.J.; Kang, C.Y.; Dimock, K. Evolution of the fusion protein gene of human parainfluenza virus 3. Virus Res. 1992, 22, 55-69. [CrossRef]

260. Henrickson, K.J.; Kuhn, S.M.; Savatski, L.L. Epidemiology and cost of infection with human parainfluenza virus types 1 and 2 in young children. Clin. Infect. Dis. 1994, 18, 770-779. [CrossRef] 
261. Fiore, A.E.; Iverson, C.; Messmer, T.; Erdman, D.; Lett, S.M.; Talkington, D.F.; Anderson, L.J.; Fields, B.; Carlone, G.M.; Breiman, R.F.; et al. Outbreak of pneumonia in a long-term care facility: Antecedent human parainfluenza virus 1 infection may predispose to bacterial pneumonia. J. Am. Geriatr. Soc. 1998, 46, 1112-1117. [CrossRef]

262. Prince, G.A.; Porter, D.D. Treatment of parainfluenza virus type 3 bronchiolitis and pneumonia in a cotton rat model using topical antibody and glucocorticosteroid. J. Infect. Dis. 1996, 173, 598-608. [CrossRef] [PubMed]

263. Downham, M.A.P.; Mcquillin, J.; Gardner, P.S. Diagnosis and Clinical Significance of Parainfluenza Virus-Infections in Children. Arch. Dis. Child. 1974, 49, 8-15. [CrossRef] [PubMed]

264. Weinberg, G.A.; Hall, C.B.; Iwane, M.K.; Poehling, K.A.; Edwards, K.M.; Griffin, M.R.; Staat, M.A.; Curns, A.T.; Erdman, D.D.; Szilagyi, P.G.; et al. Parainfluenza Virus Infection of Young Children: Estimates of the Population-Based Burden of Hospitalization. J. Pediatr. 2009, 154, 694-699. [CrossRef] [PubMed]

265. Mao, N.Y.; Ji, Y.X.; Xie, Z.D.; Wang, H.H.; Wang, H.L.; An, J.J.; Zhang, X.X.; Zhang, Y.; Zhu, Z.; Cui, A.L.; et al. Human Parainfluenza Virus-Associated Respiratory Tract Infection among Children and Genetic Analysis of HPIV-3 Strains in Beijing, China. PLoS ONE 2012, 7, e0043893. [CrossRef] [PubMed]

266. Simmonds, A.; Munoz, J.; Montecalvo, M.; Clones, B.; LaGamma, E.F. Outbreak of Parainfluenza Virus Type 3 in a Neonatal Intensive Care Unit. Am. J. Perinat. 2009, 26, 361-364. [CrossRef] [PubMed]

267. Costa, L.D.C.; Camargos, P.A.M.; Brand, P.L.P.; Fiaccadori, F.S.; Souza, M.B.D.D.E.; Cardoso, D.D.D.; Castro, I.D.; Minamisavas, R.; da Costa, P.S.S. Asthma exacerbations in a subtropical area and the role of respiratory viruses: A cross-sectional study. BMC Pulm. Med. 2018, 18, 109. [CrossRef] [PubMed]

268. Wang, F.; Zhao, L.Q.; Zhu, R.N.; Deng, J.; Sun, Y.; Ding, Y.X.; Tian, R.; Qian, Y. Parainfluenza Virus Types 1, 2, and 3 in Pediatric Patients with Acute Respiratory Infections in Beijing During 2004 to 2012. Chin. Med. J. 2015, 128, 2726-2730.

269. Matsuse, H.; Kondo, Y.; Saeki, S.; Nakata, H.; Fukushima, C.; Mizuta, Y.; Kohno, S. Naturally occurring parainfluenza virus 3 infection in adults induces mild exacerbation of asthma associated with increased sputum concentrations of cysteinyl leukotrienes. Int. Arch. Allergy Immunol. 2005, 138, 267-272. [CrossRef] [PubMed]

270. Ottolini, M.G.; Porter, D.D.; Blanco, J.C.; Prince, G.A. A cotton rat model of human parainfluenza 3 laryngotracheitis: Virus growth, pathology, and therapy. J. Infect. Dis. 2002, 186, 1713-1717. [CrossRef] [PubMed]

271. Mascoli, C.C.; Gower, T.A.; Capilupo, F.A.; Metzgar, D.P. Further studies on the neonatal ferret model of infection and immunity to and attenuation of human parainfluenza viruses. Dev. Biol. Stand. 1976, 33, 384-390. [PubMed]

272. Chang, P.W.; Hsiung, G.D. Experimental infection of parainfluenza virus type 5 in mice, hamsters and monkeys. J. Immunol. 1965, 95, 591-601. [PubMed]

273. Burke, C.W.; Bridges, O.; Brown, S.; Rahija, R.; Russell, C.J. Mode of parainfluenza virus transmission determines the dynamics of primary infection and protection from reinfection. PLoS Pathog. 2013, 9, e1003786. [CrossRef] [PubMed]

274. Akk, A.M.; Simmons, P.M.; Chan, H.W.; Agapov, E.; Holtzman, M.J.; Grayson, M.H.; Pham, C.T. Dipeptidyl peptidase I-dependent neutrophil recruitment modulates the inflammatory response to Sendai virus infection. J. Immunol. 2008, 180, 3535-3542. [CrossRef] [PubMed]

275. McWilliam, A.S.; Marsh, A.M.; Holt, P.G. Inflammatory infiltration of the upper airway epithelium during Sendai virus infection: Involvement of epithelial dendritic cells. J. Virol. 1997, 71, 226-236. [PubMed]

276. Grayson, M.H.; Ramos, M.S.; Rohlfing, M.M.; Kitchens, R.; Wang, H.D.; Gould, A.; Agapov, E.; Holtzman, M.J. Controls for lung dendritic cell maturation and migration during respiratory viral infection. J. Immunol. 2007, 179, 1438-1448. [CrossRef]

277. Kim, E.Y.; Battaile, J.T.; Patel, A.C.; You, Y.; Agapov, E.; Grayson, M.H.; Benoit, L.A.; Byers, D.E.; Alevy, Y.; Tucker, J.; et al. Persistent activation of an innate immune response translates respiratory viral infection into chronic lung disease. Nat. Med. 2008, 14, 633-640. [CrossRef]

278. Grayson, M.H.; Cheung, D.; Rohlfing, M.M.; Kitchens, R.; Spiegel, D.E.; Tucker, J.; Battaile, J.T.; Alevy, Y.; Yan, L.; Agapov, E.; et al. Induction of high-affinity IgE receptor on lung dendritic cells during viral infection leads to mucous cell metaplasia. J. Exp. Med. 2007, 204, 2759-2769. [CrossRef] 
279. Cheung, D.S.; Ehlenbach, S.J.; Kitchens, R.T.; Riley, D.A.; Thomas, L.L.; Holtzman, M.J.; Grayson, M.H. Cutting Edge: CD49d+ Neutrophils Induce FceRI Expression on Lung Dendritic Cells in a Mouse Model of Postviral Asthma. J. Immunol. 2010, 185, 4983-4987. [CrossRef]

280. Thomas, M.A.; Buelow, B.J.; Nevins, A.M.; Jones, S.E.; Peterson, F.C.; Gundry, R.L.; Grayson, M.H.; Volkman, B.F. Structure-function analysis of CCL28 in the development of post-viral asthma. J. Biol. Chem. 2015, 290, 4528-4536. [CrossRef]

281. Cheung, D.S.; Sigua, J.A.; Simpson, P.M.; Yan, K.; Hussain, S.R.A.; Santoro, J.L.; Buell, E.J.; Hunter, D.A.; Rohlfing, M.; Patadia, D.; et al. Cysteinyl leukotriene receptor 1 expression identifies a subset of neutrophils during the antiviral response that contributes to postviral atopic airway disease. J. Allergy Clin. Immunol. 2018, 142, 1206-1217. [CrossRef]

282. Mori, I.; Komatsu, T.; Takeuchi, K.; Nakakuki, K.; Sudo, M.; Kimura, Y. Parainfluenza virus type 1 infects olfactory neurons and establishes long-term persistence in the nerve tissue. J. Gen. Virol. 1995, 76 Pt 5, 1251-1254. [CrossRef]

283. Lee, A.M.; Fryer, A.D.; van Rooijen, N.; Jacoby, D.B. Role of macrophages in virus-induced airway hyperresponsiveness and neuronal M2 muscarinic receptor dysfunction. Am. J. Physiol. Lung Cell Mol. Physiol. 2004, 286, L1255-L1259. [CrossRef] [PubMed]

284. Castleman, W.L.; Sorkness, R.L.; Lemanske, R.F.; Grasee, G.; Suyemoto, M.M. Neonatal Viral Bronchiolitis and Pneumonia Induces Bronchiolar Hypoplasia and Alveolar Dysplasia in Rats. Lab. Investig. 1988, 59, 387-396. [PubMed]

285. Castleman, W.L.; Sorkness, R.L.; Lemanske, R.F., Jr.; McAllister, P.K. Viral bronchiolitis during early life induces increased numbers of bronchiolar mast cells and airway hyperresponsiveness. Am. J. Pathol. 1990, 137, 821-831. [PubMed]

286. Kumar, A.; Sorkness, R.L.; Kaplan, M.R.; Lemanske, R.F., Jr. Chronic, episodic, reversible airway obstruction after viral bronchiolitis in rats. Am. J. Respir. Crit. Care Med. 1997, 155, 130-134. [CrossRef] [PubMed]

287. Sorkness, R.L.; Gern, J.E.; Grindle, K.A.; Mosser, A.G.; Rosenthal, L.A.; Mikus, L.D.; Lemanske, R.F., Jr. Persistence of viral RNA in 2 rat strains differing in susceptibility to postbronchiolitis airway dysfunction. J. Allergy Clin. Immunol. 2002, 110, 607-609. [CrossRef] [PubMed]

288. Mikus, L.D.; Rosenthal, L.A.; Sorkness, R.L.; Lemanske, R.F., Jr. Reduced interferon-gamma secretion by natural killer cells from rats susceptible to postviral chronic airway dysfunction. Am. J. Respir. Cell. Mol. Biol. 2001, 24, 74-82. [CrossRef]

289. Rosenthal, L.A.; Mikus, L.D.; Tuffaha, A.; Mosser, A.G.; Sorkness, R.L.; Lemanske, R.F., Jr. Attenuated innate mechanisms of interferon-gamma production in rats susceptible to postviral airway dysfunction. Am. J. Respir. Cell. Mol. Biol. 2004, 30, 702-709. [CrossRef]

290. Uhl, E.W.; Clarke, T.J.; Hogan, R.J. Differential expression of nuclear factor-kappaB mediates increased pulmonary expression of tumor necrosis factor-alpha and virus-induced asthma. Viral. Immunol. 2009, 22, 79-89. [CrossRef]

291. Uhl, E.W.; Clarke, T.J.; Lester, C.; Hogan, R.J. Rats Susceptible to Virus-Induced Asthma Have a Persistent Virus-Induced Change in the Predominant Pulmonary Form of the NF-kappa B Inhibitor I kappa B alpha. Vet. Pathol. 2010, 47, 1021-1027. [CrossRef]

292. Allander, T.; Tammi, M.T.; Eriksson, M.; Bjerkner, A.; Tiveljung-Lindell, A.; Andersson, B. Cloning of a human parvovirus by molecular screening of respiratory tract samples. Proc. Natl. Acad. Sci. USA 2005, 102, 12891-12896. [CrossRef] [PubMed]

293. Bastien, N.; Brandt, K.; Dust, K.; Ward, D.; Li, Y. Human Bocavirus infection, Canada. Emerg. Infect. Dis. 2006, 12, 848-850. [CrossRef] [PubMed]

294. Lau, S.K.; Yip, C.C.; Que, T.L.; Lee, R.A.; Au-Yeung, R.K.; Zhou, B.; So, L.Y.; Lau, Y.L.; Chan, K.H.; Woo, P.C.; et al. Clinical and molecular epidemiology of human bocavirus in respiratory and fecal samples from children in Hong Kong. J. Infect. Dis. 2007, 196, 986-993. [CrossRef] [PubMed]

295. Allander, T.; Jartti, T.; Gupta, S.; Niesters, H.G.; Lehtinen, P.; Osterback, R.; Vuorinen, T.; Waris, M.; Bjerkner, A.; Tiveljung-Lindell, A.; et al. Human bocavirus and acute wheezing in children. Clin. Infect. Dis. 2007, 44, 904-910. [CrossRef] [PubMed]

296. Kesebir, D.; Vazquez, M.; Weibel, C.; Shapiro, E.D.; Ferguson, D.; Landry, M.L.; Kahn, J.S. Human bocavirus infection in young children in the United States: Molecular epidemiological profile and clinical characteristics of a newly emerging respiratory virus. J. Infect. Dis. 2006, 194, 1276-1282. [CrossRef] [PubMed] 
297. Vallet, C.; Pons-Catalano, C.; Mandelcwajg, A.; Wang, A.; Raymond, J.; Lebon, P.; Gendrel, D. Human bocavirus: A cause of severe asthma exacerbation in children. J. Pediatr. 2009, 155, 286-288. [CrossRef] [PubMed]

298. Yan, Z.; Feng, Z.; Sun, X.; Zhang, Y.; Zou, W.; Wang, Z.; Jensen-Cody, C.; Liang, B.; Park, S.Y.; Qiu, J.; et al. Human Bocavirus Type-1 Capsid Facilitates the Transduction of Ferret Airways by Adeno-Associated Virus Genomes. Hum. Gene Ther. 2017, 28, 612-625. [CrossRef] [PubMed]

299. Kim, H.Y.; Chang, Y.J.; Subramanian, S.; Lee, H.H.; Albacker, L.A.; Matangkasombut, P.; Savage, P.B.; McKenzie, A.N.; Smith, D.E.; Rottman, J.B.; et al. Innate lymphoid cells responding to IL-33 mediate airway hyperreactivity independently of adaptive immunity. J. Allergy Clin. Immunol. 2012, 129, 216-227. [CrossRef]

300. Juno, J.A.; Keynan, Y.; Fowke, K.R. Invariant NKT Cells: Regulation and Function during Viral Infection. PLoS Pathog. 2012, 8, e1002838. [CrossRef]

301. Morita, H.; Moro, K.; Koyasu, S. Innate lymphoid cells in allergic and nonallergic inflammation. J. Allergy Clin. Immunol. 2016, 138, 1253-1264. [CrossRef]

(C) 2018 by the authors. Licensee MDPI, Basel, Switzerland. This article is an open access article distributed under the terms and conditions of the Creative Commons Attribution (CC BY) license (http:/ / creativecommons.org/licenses/by/4.0/). 